\title{
İlköğretim Matematik Öğretmen Adaylarının Uzamsal Görselleștirme Becerilerinin SOLO Modeli ile İncelenmesi
}

\author{
Arş. Gör. Sevda GÖKTEPE* \\ Yıldız Teknik Üniversitesi, Eğitim Fakültesi, Davutpaşa Kampüsü \\ Esenler / İstanbul / Türkiye \\ Doç. Dr. Ahmet Şükrü ÖZDEMİR \\ Marmara Üniversitesi, Eğitim Fakültesi, Göztepe Kampüsü \\ Kadıköy / İstanbul / Türkiye
}

\begin{abstract}
Özet
SOLO modeli öğrencilerin bilgi ve becerilerini değerlendirmek için kullanılan bir taksonomidir ve öğretmen adaylarının uzamsal görselleştirme becerilerini değerlendirmek için alternatif bir araç olarak kullanılabilir. Araştırmanın amacı ilköğretim matematik öğretmen adaylarının uzamsal yeteneğin bileşenlerinden biri olan uzamsal görselleştirme becerilerini SOLO modeli ile incelemektir. Çalışma kapsamında 81 öğretmen adayı arasından Purdue Uzamsal Görselleştirme Testi'ne göre seçilen 6 kişi ile klinik mülâkatlar gerçekleştirilmiştir. Veriler Purdue Uzamsal Görselleştirme Testi ve araştırmacılar tarafından geliştirilen geometri başarı testi aracılığıla top-


lanmıştır. Klinik mülâkatlar sonunda elde edilen verilerin analizi için ses kayıt cihazına kaydedilen görüşmeler yazılı metin hâline dönüştürülmüştür. Görüşmelerden elde edilen öğrenci cevapları pilot uygulama sonunda oluşturulan değerlendirme ölçeği yardımıyla incelenmiş ve öğrenci cevaplarının SOLO taksonomisine göre hangi düşünme seviyesine girdiği betimsel analiz yapılarak belirlenmiştir. Elde edilen verilere göre ilköğretim matematik öğretmen adaylarının uzamsal görselleştirme becerileri ağırlıklı olarak SOLO modelinin Çok Yönlü Yapı düşünme seviyesindedir. Ayrıca araştırmadan elde edilen bulgulara göre öğretmenlere, öğretmen adaylarına ve araştırmacılara önerilerde bulunulmuştur.

Anahtar Kelimeler: Uzamsal görselleştirme becerisi; SOLO modeli; Geometri öğretimi; İlköğretim matematik öğretmen adayları.

\title{
Examing Elementary Mathematics Teacher Landidates' Special Visualization Skills by SOLO Model
}

\begin{abstract}
SOLO model is a taxonomy used to evaluate students' knowledge and skills and it can be used as an alternative means to assess the teacher candidates' spatial visualization skills. The purpose of the study is to examine elementary mathematics teacher candidates' spatial visualization skills which are one of the components of spatial ability according to SOLO model. It is a qualitative research study. Six people selected from 81 according to Purdue Spatial Visualization Test had clinical interviews. Data was collected through Purdue Spatial Visualization Test and geometry achievement test developed by the researchers. The recorded interviews which were saved via audio recording device were transformed into written text for analyzing the data. The answers of the students obtained from interviews were examined with help of the scale for the assessment generated at the end of pilot study. Students' answers were put into SOLO thinking levels by doing descriptive analysis. Most of the teacher candidates are at the multistructural level in spatial visualization skills according to SOLO model thinking levels. Recommendations for further research to teac-
\end{abstract}


hers, the teacher candidates and researchers are made according to findings of the study.

Keywords: Spatial visualization skills; SOLO model; Geometry teaching; Elementary mathematics teacher candidates.

\section{Extended Summary}

\section{Purpose}

It is difficult to measure the comprehension level of a student about a topic or a concept. Thus, there is an increasing tendency towards alternative measurement methods lately. SOLO model can be used as an alternative to measure and evaluate spatial visualization skills. Teachers play a critical role in the improvement of spatial skills and three dimension thinking ability. Before they started their professional career, it is important to know the teacher candidates' spatial visualization skills levels. The main aim of this study is to evaluate the spatial visualization abilities of mathematics teacher candidates with SOLO model.

\section{Methods}

Qualitative research methods were used for this study. In the first stage 81 teacher candidates spatial abilities was measured by using Purdue Spatial Visualization Test. In the second stage clinical interviews were done with 6 teacher candidates that were chosen according to Purdue Spatial Visualization Tests' results. "Geometry achievement test" was used to measure spatial visualization skills of prospective teachers among different dimensions developed by researchers. After the pilot study, an assessment scale was generated to evaluate the teacher candidates' responses. Qualitative data was evaluated and 
analyzed one by one and the teacher candidates' answers were put in SOLO thinking levels. Clinical interviews recorded by audio recording device were transformed into written text and also notes taken by researcher were added.

\section{Results}

According to results of the research, most of the teacher candidates are at the multistructural level in spatial visualization abilities according to SOLO model thinking stages. Answers of the teacher candidates' who are lowest level are mostly at unistructural level. Looking at the middle level teacher candidates', they are at multistructural thinking level according to SOLO model. Similarly high level teachers are at multistructural level. Also all prospective teachers answer levels in the spatial visualization questions which require transition among different dimensions are lower than the relational structure level. Thus, there is no deep comprehension.

\section{Discussion}

According to data which obtained from clinical interviews, most of the teacher candidates' are at multistructural thinking level of SOLO model in terms of the spatial visualization skills. In terms of this result, prospective teachers use more than one information to reach the answers but cannot comprehend the relationship between these data. Therefore, some inconsistencies were found in their responses.

As for the teacher candidates' who have low spatial visualization skills mostly in unistructural thinking level, they focus on problems, but 
they use only a single data associated with solution. They cannot understand the place of their data in the whole and the relationship with other data. According to Hattie and Brown (2004) as the answers given at unistructural level are not in-depth, it can be said that low level teacher candidates' have superficial learning. As for the middle level teacher candidates' are at multistructural thinking level; if spatial visualization skills of student teachers improves then their thinking level according to SOLO model increases. Bilal's answers, who is one of the teacher candidates' with high level spatial visualization ability, are more advanced. Three of his responses are at relational level and two of them are extended abstract level. A great number of studies point out that in math courses various activities must be taken place for the development of spatial ability. Baki and Güven (2007), Kösa (2011), Uygan (2011) indicate that dynamic geometry programs develop students' spatial ability. Besides, Arıcı (2012) states that origami activities are effective in the development of spatial ability.

\section{Conclusion}

According to data which is obtained from clinical interviews, spatial visualization skills of elementary mathematics teacher candidates' are at multistructural level based on SOLO model. Spatial ability is important not only for mathematics courses but also for every area of our lives. For training students to develop their spatial abilities, teachers are required to have high level spatial abilities. Therefore, there is a great importance of teacher education. Although space geometry is mostly subject of secondary school education, there are many short- 
comings of the students when they start this undergraduate program.

Due to space geometry contains very high-level abstract concepts' the recommendations which are made may be helpful for further studies.

To determine the levels of teacher candidates' or the students' geometrical thinking, mostly studies examing this plane geometry thinking levels were done. There are few studies about thinking levels of students in space geometry. In this study spatial visualization that is a component of spatial ability was used for examining teacher candidates' thinking levels in space geometry, but other components which determined by other researchers can be investigated. In addition, answers levels of student teachers can be identified in other space geometry topics.

Data which is obtained from this study were analyzed according to SOLO model thinking level; however same data can be analyzed with different thinking levels. Comparison can be made between the two models, thus an opportunity from a different perspective is also taken up. In this way, if there are missing and overlooked aspects, they can be added. As to SOLO model is classifying students' answer levels instead of classifying students in a class as individuals, it may be recommended to researchers who wish to use an alternative method for evaluation.

\section{Giriş}

Geometri; matematiğin uzay, boyut kavramları ile ilgilenen ve şekiller üzerine yoğunlaşan en eski dallarından biridir (Jones, 2000). 
Geometrik düşünme kişilerin şekillerin özelliklerini öğrenmesine, şekilleri tanımasına ve şekillerin özellikleriyle ilgili bilgi birikimine sahip olmasına bağlıdır. Geometrik kavramların öğretiminde öğrencilerin bu alandaki düşünme becerilerinin farkında olunması etkili eğitim-öğretim faaliyetleri için gereklidir. Bunun için de bireyin geometrik sezgiye ve bilgiye sahip olması, geometrik düşünme ve geometrik problem çözme becerisine sahip olması gerekmektedir (Han, 2007). Benzer şekilde Baki (2008)'de geometri eğitiminin genel amacını; öğrencinin kendi fiziksel dünyasını, çevresini, evreni açıklamada ve problem çözme sürecinde geometriyi kullanabilmesi şeklinde ifade etmiştir.

Matematik ve geometri, fen ve diğer alanlarla da ilgili olduğundan ayrıca önem arz etmektedir. Öğrencilerin geometriyi öğrenmeleri uzamsal algılarının gelişimine katkı sağlar ve matematiksel beceri gerektiren çeşitli meslekler için ve daha ileri düzeydeki matematik ve diğer bilimler için onları hazırlar (French, 2004; Sherard, 1981). Geometrik düşünme becerileri matematiğin dışında birçok meslek grubu için örneğin mühendisler, mimarlar, heykeltıraşlar, fizikçiler için de önemlidir (Olkun, 2003; Tekin, 2007). Geometrik şekillerin sınıflandırılması ve özelliklerinin anlaşılması gerçek yaşam ve matematiğin diğer alanlarıyla (ölçme, cebir ve rasyonel sayılar) ilgili problemlerin çözümüne katkı sunmaktadır (NCTM, 2000). Terao, Koedinger, Sohn, Anderson ve Carter (2004) çalışmasında matematiksel düşünmenin sembolik ve görsel-uzamsal sistemlerin arasındaki ilişkiden ortaya çıktığını söylemiştir. Örneğin sözel cebirsel problemler aslında 
sadece dilsel süreçlerden oluşan problemler değildir. Onların çözülmesi için de görsel-uzamsal sistemlerin çalışması gereklidir. Dolayısıyla hem matematikte hem de diğer disiplinlerde uzamsal yetenek önemli bir yetenek olarak karşımıza çıkmaktadır.

Geometrik düşüncenin gösterdiği gelişimin bilinmesi uzamsal düşüncenin geliştirilmesine yönelik çalışmaların yönlendirilmesinde önemlidir. Uzayı tanıma ve uzamsal düşünmenin gelişimi geometrik düşüncenin gelişimi ile paralellik gösterir (Altun, 2009). Uzamsal düşünme ise bireyin nesneleri ve karşılaşılan durumu görsel olarak zihninde oluşturma becerisidir. Ayrıca uzamsal düşünme problem çözerken açıklayıcı şekiller çizmeyi, sözel problemler verildiğinde verileri zihninde organize etmeyi, tablo ve grafik oluşturmayı, geometrik şekilleri akılda daha kolay tutmayı ve aralarındaki ilişkileri daha iyi kavramayı gerektirir (Turgut, 2010). Uzamsal ilişkileri belirleme konusunda yeterli olan ve geometrik kavramları iyi bilen öğrencilerin daha ileri düzeyde matematik konularını öğrenmede hazırbulunuşluk düzeyleri daha yüksek olmaktadır (Hoover, 1996).

Ayrıca geometri, öğrencilere matematik teorilerini gerçek hayat durumlarıyla birleştirerek çıkarımsal bir yapı oluşturma imkânı sağladığından matematik müfredatında kritik bir rol oynamaktadır (Hvizdo, 1992).

Ülkemizde 2004-2005 eğitim-öğretim y1lından itibaren 1-5. s1nıflarda, 2005-2006 yılından itibaren ise 6-8. sinıflarda uygulanmaya başlayan yeni ilköğretim matematik öğretim programında yer alan 
öğrenme alanlarından biri de geometri öğrenme alanıdır. 2012-2013 eğitim-öğretim yılından itibaren ise ilkokul ve ortaokul şeklinde ayrılan sistemde matematik dersinin haricinde yer alan seçmeli derslerde de öğrencilerin uzamsal yetenekleri ile ilgili kazanımlar bulunmaktadır. 5., 6., 7. ve 8. sınıflar için zekâ oyunları ve matematik uygulamalar1 dersi de bu kapsamdadır (MEB, 2012a, 2012b).

1-5. sınıf düzeyinde müfredatta şekiller bütün olarak verilerek adlandırılmıştır. Gruplandırma cisimlerin şekillerine, cinslerine ve görünümlerine göre yapılmıştır ve benzerlikler esas alınmıştır. Kazandırılması istenen bilgi ve beceriler, çevrelerindeki nesneleri gözlemleme, kendilerinin materyalleri kullanarak keşfetmelerini sağlama yoluyla verilmeye çalışılmaktadır. Soyut bilgi aktarımına fazla gidilmemektedir (MEB, 2009a).

6-8. sınıfta ilköğretim matematik öğretim programındaki öğrenme alanlarının sayıları artırılarak ve yeni kavramlar eklenerek karşımıza çıkmaktadır. Dönüşüm geometrisi, iz düşümü, örüntü ve süslemeler, geometrik cisimler alt öğrenme alanları özellikle uzamsal yetenekler ile ilgilidir. Bu alt öğrenme alanlarının altında bulunan öteleme, dönme, yansıma ve perspektif gibi konularda ise uzamsal yetenekleri geliştirme ile uzay ve boyut kavramlarını kazandırma ilgili kazanımlar bulunmaktadır. İlkokul ve ortaokul müfredatında uzamsal yetenekler ile ilgili kazanımlar özellikle geometri öğrenme alanında yer almakla birlikte ölçme öğrenme alanında da konuyla ilgili önemli sayıda kazanım vardır. İlköğretim düzeyinde uzay kavramının gelişimi 
için boyut kavramı üzerinde informal olarak durulmuştur. Şekil ve cisimler boyutlarına göre sınıflandırılmıştır (MEB, 2009b).

İlköğretim düzeyinde uzamsal yeteneğin uzamsal görselleştirme bileşeni ile ilgili kazanımlar aslında daha çok geometri öğrenme alanında yer almaktadır. Örneğin; verilen nesneleri farklı şekillerde döndürme, açınımı verilen şekilleri oluşturarak iki boyut ile üç boyut arasında geçişler yapma uzamsal görselleştirme becerisi ile ilgilidir. $\mathrm{Bu}$ beceri ile ilgili programda yer alan kazanımlara bir örnek "Koordinat düzleminde bir çokgenin eksenlerden birine göre yansıma, herhangi bir doğru boyunca öteleme ve orijin etrafındaki dönme altında görüntülerini belirleyerek çizer." verilebilir.

Bütün sınıf düzeylerine bakıldığında ise geometri derslerinin ağırlıklı olarak iki boyutlu Öklid geometrisine yönelik olduğu görülmektedir. Bunun yanı sıra üç boyutlu uzay geometri ve uzayın analitiği de ortaöğretim ve yükseköğretim düzeyinde okullarda az da olsa okutulmaktadır. Ancak ortaöğretimde uzay geometri konularının yer aldığı geometri dersleri genelde varılmak istenen hedeflere ulaşılmadan tamamlanmaktadır (Kösa, 2011). Bunun başlıca sebeplerinden biri olarak üç boyutlu geometrik cisimlerin görünümlerinin yorumlanmasında güçlük çekilmesi gösterilmektedir (Accascina ve Rogora, 2006). Yapılan bir araştırma sonucuna göre 15 yaş grubundaki ögrencilere en itici gelen matematik konuları uzay geometridir. Araştırmaya katılan öğretmenlerin sadece \% 10’u, uzay geometri konularını öğretmede başarılı olduklarını belirtmişlerdir. Uzay geometri öğretiminde karşılaşılan zorlukların temel nedeni olarak da öğrencilerin üç boyutta gö- 
rememesi olarak gösterilmektedir (Bako, 2003). Araştırmacı üzerinde yaşadığımız dünya üç boyutlu olduğundan ve öğrenciler çevrelerini anlamak için üç boyutlu geometriye daha çok ihtiyaç duyduklarından geometri öğretiminde uzay geometriye daha fazla önem verilmesi gerektiğini belirtmiştir.

Çok sayıda çalışma öğrencilerin ihtiyaçları olduğu kadar ya da kendilerinden öğrenilmesi beklenen kadar geometriyi öğrenemediklerini belirtmektedir (Clements ve Battista, 1992). Bu aşamada öğretmenlere büyük görev düşmektedir. Hem dünyada hem de Türkiye'de öğretmenin yeterli konu bilgisine sahip olması gerektiği yani yeterli matematik bilgisinin olması gerektiği vurgulanmaktadır. Öğretimin istenilen seviyede gerçekleşebilmesi için öğretmenin konu ile ilgili ayrıntılı bilgi sahibi olması gerektiğgi belirtilmektedir (Fennema ve Loef, 1992; Kahan, Cooper ve Bethea, 2003). Ayrıca araştırmalara göre öğretmenin matematik bilgisi, öğrenme ortamlarında verdiği kararları da etkilemektedir (Fennema ve Loef, 1992; Lloyd ve Wilson, 1998; Van Dooren, Verschaffel ve Onghena, 2002). Shulman (1986) bir öğretmenin sahip olması gereken üç tür bilgi olduğunu belirtmektedir. Bunlar; konu bilgisi (subject matter knowledge), pedagojik içerik bilgisi (pedogogical content knowledge) ve müfredat bilgisi (curriculum knowledge) dir. Türkiye'de ise Millî Eğitim Bakanlığı öğretmenlerin sahip olması gereken yeterlilikleri özel alan bilgi ve becerileri, eğitim ve öğretme yeterlilikleri, genel kültür bilgi ve becerileri olmak üzere üç ana başlık altında toplamıştır (MEB, 2002). 
Öğretmenlerin öğrencilerin hangi konularda eksikliklerini olduğunu bilmesi kadar kendi öğrenmelerini sorgulaması da önemlidir. $\mathrm{Bu}$ kısım Shulman (1986) tarafından belirtilen konu bilgisi ile ilgilidir. Öğretmenin neyi bilip bilmediğinin farkında olması etkili bir öğretim için gereklidir. $\mathrm{Bu}$ farkındalığın oluşturulmasında da öğretmenlerin durumlarını, seviyelerini tespit eden çalışmaların yapılması faydalı olabilir. Bu amaçla yapılan çalışmalarda Piaget'in gelişim kuramı yardımcı olarak kullanılabilir. Piaget zihinsel aktivitelere mantıksal bir sıra içinde bireylerin yaşlarına göre yer vererek her yaş düzeyine uygun bir tespit yapmaya olanak tanıyan bir kuram geliştirmiştir. Ancak bazı öğrenciler aynı yaş düzeyinde farklı evrelerde olabilmektedirler. $\mathrm{Bu}$ durum Piaget tarafindan "decalage" olarak adlandırılmıştır ve bu duruma okullarda sık sık rastlanmaktadır. Bir öğrenci matematikte erken soyut düzeyde iken tarihte somut işlemler düzeyinde olabilir. Hatta matematikte bir gün somut işlemler düzeyinde iken ertesi gün soyut işlemler düzeyinde olabilir (Çelik, 2007). SOLO modeli de bu durumun yetersizliği üzerine ortaya çıkmıştır. Dikkatleri bireylerin bilişsel evresine değil verdiği cevaba çekmiştir. SOLO modelinin kritik noktası öğrencinin cevabı değil, bu cevaba ulaşırken kullandığı düşünme süreçleridir (Biggs ve Collis, 1991; Pegg ve Tall, 2004).

\section{Uzamsal Yetenek}

Uzamsal yeteneğin önemi konusunda araştırmacılar arasında büyük bir fikir birliği varken, tanımı hususunda bu birlik bozulmaktadır. D'Oliveira (2004) uzamsal yeteneğin ifade edilmesinde ortaya çıkan karışıklığın nedenlerini uzamsal yeteneğin farklı araştırmacılar 
tarafından farklı şekilde tanımlanması, farklı sayıda ve farklı isimlerde bileşenlerinin ortaya koyulması ve uzamsal yetenek testlerinin hangi uzamsal bileşeni ölçtüğüne ilişkin farklı açıklamaların yapılması olarak belirtmiştir.

Literatür incelendiğinde uzamsal düşünme, uzamsal algı, uzamsal akıl yürütme gibi kavramlar uzamsal yetenek yerine kullanılmaktadır (Clements ve Battista, 1992; NCTM, 2000; Olkun, 2003). Türkiye'de ve dünyada uzamsal yetenek çerçevesinde kullanılan tanımlara örnek olarak aşağıdakiler verilebilir:

Uzamsal yetenek kavramı French (1951) tarafından uzaydaki üç boyutlu nesnelerin hareketlerinin canlandırması ve bireyin zihninde nesneleri hareket ettirebilme yeteneği olarak tanımlanmıştır (akt. McGee, 1979). Stockdale ve Possin (1998), uzamsal becerileri kişinin kendi ile çevresi arasındaki veya kendi dışındaki nesneler arasındaki uzamsal ilişkiyi kavrayabilme becerisi olarak tanımlamışlardır. Bu iki tanımdan da yola çıkarak uzamsal yetenek, özellikle uzaydaki üç boyutlu nesnelerin hem kendi hareketlerinin hem de birbirleriyle olan uzamsal ilişkilerinin anlaşılması olarak ifâde edilebilir.

Uzamsal yeteneğin genel tanımında olduğu gibi bileşenlerinin belirlenmesi hususunda da birlik yoktur. Belirlenen bileşenlerden biri de uzamsal görselleştirme bileşenidir (Burnet ve Lane, 1980; Clements, 1998; Clements ve Battista, 1992; McGee, 1979; Olkun ve Altun, 2003). Yapılan tanımlamalardan birkaçı şu şekildedir: 
Clements (1998)'e uzamsal görselleştirme göre iki boyutlu ve üç boyutlu nesnelerin zihinde canlandırılan hareketlerini anlama ve gerçekleştirebilme becerisidir. Olkun ve Altun (2003) uzamsal görselleştirmeyi bir ya da birden çok parçadan oluşan iki ve üç boyutlu nesnelerin uzayda hareket ettirilmeleri sonucu oluşacak yeni durumlarını zihinde canlandırma becerisi olarak tanımlamışlardır. İki ve üç boyutlu uzayda nesnelerin hareketlerini hayâl edebilme ve bu hareketleri kavrama becerisi de Clements ve Battista (1992) tarafından uzamsal görselleştirme olarak adlandırılmıştır. Ayrıca uzamsal görselleştirme bir ya da birden çok parçadan oluşan iki ve üç boyutlu şekillerin ve bunların parçalarına ait görüntülerin üç boyutlu uzayda hareket ettirilmesi ile oluşan yeni şekilleri zihinde canlandırabilmedir (Burnet ve Lane, 1980). Bu tanımlardan hareketle genel anlamda uzamsal görselleştirme iki ve üç boyutlu nesnelerin çeşitli hareketleri sonunda oluşacak durumları zihinde canlandırabilme becerisidir diyebiliriz.

McGee (1979) uzamsal görselleştirmeyi görsel olarak verilen bir nesnenin açılımını yapma, zihinde döndürme, bükme veya tersyüz etme becerisi olarak tanımlamıştır. Uzamsal görselleştirme becerileri, nesneleri oluşturan parçaların katlama, geri açma (McGee, 1979), yeniden düzenleme, yüzeyi kaplama (Battista, Wheatley ve Talsma, 1989; Smith, Olkun ve Middleton, 1999) etkinliklerini içerebilir. Bu çalışmada McGee (1979)'nin uzamsal görselleștirme tanımı temel alınmıştır. Ayrıca kapalı hâli verilen şekillerin açılımlarının yapılması ya da açık hâli verilen şeklin kapalı hâlinin elde edilmesini içeren sorulara; yansıma, simetri, öteleme faaliyetlerini içeren örüntüsel 
problemlere bu kapsamda çalışmada geometri testi içinde yer verilmiştir.

\section{SOLO Modeli}

SOLO (Structure of the Observed Learning Outcomes) farkl1 konu alanı ve seviyelerde öğrencilerin becerileri ve bilişsel bilgilerini değerlendirmek amacıyla kullanılan bir taksonomidir (Biggs ve Collis, 1991; Pegg ve Tall, 2004).

SOLO modelinde yer alan her bir düşünme evresi beş alt seviyeyi (levels of response) içermektedir. Bu seviyelere "SOLO taksonomisi" de denilmektedir. Bunlar yapı öncesi (Prestructural), Tek Yönlü Yapı (Unistructural), Çok Yönlü Yapı (Multistructural), İlişkisel (Relational) Yapı ve Genişletilmiş Soyut (Extended Abstract) seviyeleridir. Cevapların karmaşıklığı arttıkça seviye yükselmektedir. Ayrıca düzey arttıkça tutarlı açıklamalar yapma, ilişkilendirme yapma, birden fazla durumu hesaba katarak düşünme becerileri de artmaktadır (Biggs ve Collis, 1991; Çelik, 2007).

SOLO taksonomisinin düşünme seviyelerine ait bilgiler aşağ1daki gibidir (Biggs ve Collis, 1991; Çelik, 2007):

Yapı Öncesi (YÖ): Öğrencilerin sorulara verdikleri cevaplar yeterli değildir. Problemde çözüm için kullanılmayan kısımlar öğrencinin dikkatinin dağılmasına yol açar. Çözüme ulaşırken kullandığı yol 
onu doğruya götürmez ve daha düşük seviyede bir evreye uygun adımlar atar.

Tek Yönlü Yapı (TY): Öğrenci probleme odaklanır ancak çözüm için sadece ilişkili bir veriyi kullanır. Kullandığı verinin bütün içindeki yerini ve diğer verilerle ilişkisini anlayamaz. Dolayısıyla cevapları tutarlı olmayabilir.

Çok Yönlü Yapı (ÇY): Cevaba ulaştıran birden fazla veriyi kullanır ancak bu veriler arasındaki ilişkiyi kavrayamaz. Bu yüzden cevaplarında bazı tutarsızlıklara rastlanabilir.

İlişkisel Yap1 (IY): Öğrenci problemin cevabına ulaştıran bütün verileri kullanır ve bunların bütün içindeki yerini ve birbirleriyle olan ilişkilerini anlar. Tutarlı bir yapı oluşturur.

Genişletilmiş Soyut Yapı (GSY): Öğrenci çözüme ulaşırken problemde yer alan verilerin ötesinde düşünür ve genellemelere ulaşır. Yeni bir düşünme biçimi oluşturulabilir.

SOLO taksonomisi farklı alanlarla birlikte matematikte de öğrencilerin belli kavramlarla ilgili anlamalarını ve matematiksel düşünme becerilerini tanımlamak ve yorumlamak için kullanılmaktadır (Groth, 2002; Jones, Langrall, Thornton ve Mogill 1997; Jones ve ark., 2000; Lam ve Foong, 1996; Lian ve Idris, 2006; Money, 2002; Pegg ve Coady, 1993; Pegg ve Davey, 1998; Wongyai ve Kamol, 2004). 
İlköğretim düzeyinde yapılan çalışmada Ardıç, Yılmaz ve Demir (2012) 8. sınıf öğrencilerinin merkezî eğilim ve yayılım ölçülerine yönelik istatistiksel okuryazarlık düzeylerinin SOLO taksonomisine göre hangi seviyede olduğunu araştırmıştır. Araştırmaya 9 öğrenci ile gerçekleştirilmiş ve öğrencilerin merkezî eğilim ve yayılım ölçülerine yönelik istatistiksel düşünme seviyelerini belirlemek için 3 soru sorulmuştur. Veriler klinik mülâkatlar ve öğrencilerle yapılan görüşmelerden elde edilmiştir. Çalışmadan elde edilen bulgulara göre öğrencilerin cevapları genellikle çok yönlü seviyedir ayrıca soyutlanmış yapı seviyesinde öğrenci cevabı bulunmamaktadır.

Ortaöğretim düzeyinde Lian ve Idris (2006) çalışmasında 10. s1nıf öğrencilerinin lineer denklemler konusunda cebirsel çözüm becerilerini ölçmek için SOLO taksonomisini kullanmıştır. İlk bölümde 40 öğrenciye 8 açık uçlu problem uygulamış, sonra 8 öğrenciyi seçerek klinik mülâkat yapmıştır. Araştırmadan elde edilen verilere göre öğrencilerin cevaplarının çoğunluğu Tek Yönlü Yapı (TY) ve Çok Yönlü Yapı (ÇY) düzeyindedir.

Yüksek öğretim düzeyinde yapılan çalışmalardan birinde Rider (2004) iki üniversiteden toplam 313 öğrenci ile çalışmış ve yarı deneysel çalışmasında çoklu gösterimlere dayalı müfredatın cebir kavramlarının sembolik, tablo ve grafik gösterimler ve aralarındaki ilişkiyi anlamaya etkisini araştırmıştır. Konu ile ilgili beş problem oluşturmuş ve her iki gruba da ön test ve son test olarak uygulamıștır. Deney grubu öğrencilerinin ön test ve son test puanları daha yüksektir. Sonra her iki gruptan sekiz öğrenci ile mülâkat yapmış ve elde edilen nitel 
veriler SOLO modeline göre incelenmiştir. Sonuçlara göre deney grubundaki öğrenciler ilişskileri daha iyi bir şekilde ortaya koymuştur.

Groth ve Berner (2006) 46 öğretmen adayı ile çalışmış ve istatistik kavramları konusundaki anlamalarını belirlemek için yazılı sınav yapmış ve soruları SOLO taksonomisi çerçevesinde değerlendirmiştir. Araştırma bulgularına göre öğretmen adaylarının cevapları genel olarak Çok Yönlü Yapı (ÇY) seviyesindedir.

Çelik (2007) nitel olarak gerçekleştirdiği çalışmasında 8 matematik öğretmen adayı ile çalışmıştır. Öğretmen adaylarının cebirsel düşünme becerilerinin değerlendirmek için 11 problem üzerinden klinik mülâkatlar gerçekleştirmiştir. SOLO modeli ile yapılan analiz sonuçlarına göre öğretmen adaylarının çoğunluğu sembolleri ve cebirsel ilişkileri kullanma, çoklu gösterimlerden yararlanma ve genellemeleri formüle etme becerilerinde ilişkilendirilmiş yapı seviyesinin altında kalmıştır.

İlköğretim, ortaöğretim ve yükseköğretim düzeylerinde matematik alanında SOLO modeli kullanılarak yapılan çalışmaların bulunduğu görülmektedir. Çalışmalar daha çok nitel araştırmalardır ancak nicel çalışmalara da rastlanmaktadır. Bu çalışma öğretmen adaylar1 ile yürütüldüğünden yükseköğretim düzeyinde yapılan çalışmalara bakıldığında uzamsal yetenek ile ilgili çalışmaya rastlanmamaktadır.

Uzamsal yeteneğin SOLO modeli ile incelendiği çalışma Koç ve diğerleri (2011) tarafindan yapılmış olup ilköğretim düzeyinde gerçekleştirilmiştir. Araştırmacılar öğrencilerin görselleştirme becerileri- 
ni SOLO modeli ile belirlemek amacıyla 15 açık uçlu sorudan oluşan Uzamsal Görselleştirme Testi geliştirmişlerdir. Soruların her biri SOLO seviyelerine uygun daha fazla karşılaşılan 4 seviyeye (tek yönlü yap1 seviyesi, çok yönlü yap1 seviyesi, ilişkisel yap1 seviyesi, genişletilmiş soyut yapı seviyesi) uygun dört alt sorudan oluşmaktadır. Geliştirilen testin 385 6-8. sınıf öğrencisi ile pilot çalışması gerçekleştirilmiş ve geçerlik ve güvenirlik çalışması yapılmıştır.

Farklı olarak Pegg ve Tall (2004) çalışmasında cebirsel düşüncenin gelişiminde SOLO modeli ile Dubinsky'nin process-object encapsulation modelini karşılaştırmıştır ve SOLO modelinin farklı seviyelerde yer alan öğrencilerin cevaplarının yapısını belirlemek için uygun olduğunu ifâde etmiştir. Bu çalışma da SOLO modelinin öğrencilerin öğrenmelerini değerlendirmede etkili bir araç olarak kullanılabileceğini göstermektedir.

\section{Araştırmanın Amacı}

Literatüre baktığımızda geometrik düşünme ya da anlama üzerine yapılan çalışmalara sıklıkla rastlanmaktadır ve bu çalışmalarda daha çok van Hiele geometrik anlama düzeyleri kullanılmıştır (örneğin, Usiskin, 1982; van Hiele, 1986; Crowley, 1987; Duatepe, 2000; Kılıç, 2003; Halat, 2006; Gökbulut, Sidekli ve Yangın, 2010). Bu çalişmalarda özellikle iki boyutlu düzlem geometride yer alan sorular üzerinden değerlendirme yapılmıştır. Ancak uzay geometride düşünmelerin nasıl gerçekleştiği ile ilgili sınırlı sayıda çalışma olduğu görülmektedir (Güven, 2006; Kösa, 2011; Guillen, 1996; Gutierrez, 
Pegg, Lawrie, 2004). Bu türden araştırmaların yapılması gerektiği düşünülerek çalışmaya yön verilmiştir.

Öğretmenlerin öğrencilerinin uzamsal yönlerini geliştirebilmeleri için kendilerini de görsel-uzamsal alanda yeterli olmaları gereklidir. Bununla birlikte öğretmen adaylarının uzay geometri derslerinde başarılı olabilmeleri için gerekli geometrik alt yapılarının ve seviyelerinin ne olduğunu bilmek faydalı olacaktır. Böylece mesleğe başlamadan önce eksiklerini görme ve tamamlama imkânı bulacaklardır.

Öğrencilerin bir konuyu ya da kavramı öğrenip öğrenmediklerini ölçmek oldukça zor bir iştir. Bu yüzden son yıllarda eğitimde dolayısıyla matematik eğitiminde alternatif ölçme değerlendirme tekniklerine bir yöneliş vardır. Bu amaçla öğretmen adaylarının uzamsal yeteneklerinin bileşenlerinden olan uzamsal görselleştirme becerilerinin ölçülmesinde ve değerlendirilmesinde SOLO modeli alternatif olarak kullanılabilir.

$\mathrm{Bu}$ araştırma, nesneleri değişik şekillerde döndürme, açık hâli verilen şekillerin kapalı görünümlerini ya da tam tersi kapalı görünümleri verilen şekillerin açılımını düşünebilme, şekillere farklı açılardan bakma konularında fikir vermesi, elde edilen veriler ışığında geometri öğretiminde nelere dikkat edilmesi gerektiği konusunda yardımcı olması açısından önem taşımaktadır. Nitekim French (2004), Sherard (1981) çalışmalarında geometri öğrenmenin matematiksel bilgiyi ilerletmede ve farklı branşlarda kullanmada ihtiyaç olduğundan bahsetmektedir. Ayrica (MEB, 2009a, 2009b, 2012a) geometrinin, 
matematik ve geometri öğretim programlarında ilköğretim, ortaöğretim ve yükseköğretim düzeyinde kaplamış olduğu yerden dolayı geometrik düşüncenin gelişimi akademik başarıyı da beraberinde getirecektir. Öğrencilerin ya da öğretmen adaylarının uzamsal yeteneklerinin farklı şekillerde değerlendirildiği çalışmalara rastlanmaktadır (Baki ve Güven, 2007; Dursun, 2010; Sevimli, 2009; Uygan, 2011; Yolcu, 2008). Bu çalışmanın diğer çalışmalardan ayrılan yönü uzamsal yeteneğin SOLO modeli aracılığıyla değerlendirilmesidir. Hem uzamsal yeteneği hem de SOLO modelini içeren ilk çalışmalardan olması itibariyle önem taşımaktadır ve gelecekte bu konuda yapılacak çalışmalara 1şık tutacaktır. Ayrıca bu araştırma öğretmenlere ve diğer araştırmacılara kaynak oluşturması bakımından da önemlidir. Öğretmenler için alternatif bir değerlendirme yöntemi olarak kullanılabileceğinden ayrıca önem taşımaktadır. İlaveten çalışmanın öğretmen adaylarının görsel yetenekleri hakkında farkındalık oluşturmasını sağlayarak onlara eksiklerini görme ve giderme olanağı sağlayabileceği düşünülmektedir.

SOLO taksonomisinin farklı matematik konularında kullanımı ile ilgili çalışmalara rastlanmaktadır (Money, 2002; Lian ve Idris, 2006; Rider, 2004; Groth, 2002; Pegg ve Tall, 2004) ancak geometri konularında (Pegg ve Davey, 1998; Jurdak, 1991) daha az sayıda çalışma vardır. Uzamsal yeteneğin SOLO modeli ile değerlendirilmesi ile ilgili bir adet çalışmaya rastlanmıştır (Koç ve ark., 2011). Dolay1sıyla yapılan ilk çalışmalardandır ve böyle bir çalışmanın yapılması SOLO taksonomisinin araştırmanın konusu olan uzamsal yetenekle 
ilgili seviyelerin nasıl belirleneceği hakkında daha ayrıntılı fikir sahibi olmayı sağlayacaktır.

Bütün bu bilgiler 1şı̆̆ında çalışmanın temel amacı ilköğretim matematik öğretmen adaylarının uzamsal görselleştirme becerilerini SOLO modeline göre incelemektir. Bu amaçla "İlköğretim matematik öğretmen adaylarının uzamsal görselleştirme becerileri SOLO taksonomisine göre hangi seviyelerde yer almaktadır?" problemine cevap aranmıştır. Ayrıca öğrencilerin cevaplarının belirlenen seviyelere göre (düşük-orta-yüksek) hangi SOLO düzeylerinde yer aldığı araştırılmıştır. İlaveten farklı boyutlar arasındaki (iki boyuttan iki boyuta, iki boyuttan üç boyuta, üç boyuttan iki boyuta, üç boyuttan üç boyuta) sorulara verdikleri cevaplar da SOLO düzeylerine göre sınıflandırılmıştır.

\section{Yöntem}

\section{Araştırmanın Modeli}

İlköğretim matematik öğretmen adaylarının uzamsal görselleştirme becerilerini inceleyen bu çalışma nitel bir araştırmadır. Creswell (1998) nitel araştırmayı, sosyal hayatı kendine has yöntemlerle anlamlandırma süreci olarak ifâde etmektedir. Genel itibariyle nitel araştırmacı gözlem, görüşme ve dokümanlardan yola çıkarak kavramları, anlamları ve ilişkileri açıklayarak araştırma sürecini sürdürür (Merriam, 1998). Son yıllarda eğitim ile ilgili araştırmalara bakıldığında nitel araştırma yöntemlerinin kullanımında artış olduğu görülmektedir (Boz ve Boz, 2006; Ubuz ve Sarı, 2008). Seçilen bir konunun derinlemesine ayrıntılı bir şekilde araştırılmasına olanak veren durum çalışması (Çepni, 2010) bu araştırmada yöntem olarak belirlenerek daha 
çok "Nasıl?", "Niçin?" ve "Ne?” sorularına cevap aranmıştır. SOLO modeli ile yapılan çalışmalar incelendiğinde (Çelik, 2007; Lian ve İdris, 2006; Ardıç, Yılmaz ve Demir 2012) hemen hepsinin nitel çalışmalar olması görülmüş ve bu çalışmanın bu bölümünde de nitel bir yöntem kullanılmasının uygun bulunmuştur.

Klinik mülâkatlar aracılığıyla niçin ve nasıl sorularına yanıt verilerek öğrencilerin düşünme süreçleri ayrıntılı bir şekilde incelenebilmektedir (Güven, 2006; Çelik ve Baki, 2007). Öğrencilerin düşüncelerini derinlemesine incelemek amacıyla öğrenciyle karşılıklı yapılan görüşmeler, klinik mülâkat olarak tanımlanmaktadır (Güven, 2006). Nitekim klinik mülâkatlar son yıllarda matematik eğitimi araştırmalarında kullanılmaya başlanmıştır (Çelik ve Baki, 2007; Dindyal, 2003; Güven, 2006; Money, 2002). Goldin (1998) klinik mülâkatların iki amaç için kullanılabileceğini belirtmektedir. Bu amaçlardan biri problem çözme yöntemi aracılığıyla bireylerin matematiksel davranışları hakkında bilgi sahibi olmadır. Dolayısıyla öğretmen adaylarının uzamsal yetenekleri problem çözme etkinlikleri aracılığıyla klinik mülâkatlar içerisinde değerlendirilmiştir. Nitel verilerin analizinde betimsel analiz yöntemi kullanılmıştır.

\section{Çalışma Grubu}

SOLO modelinin düşünme evreleri incelendiğinde soyut (formal) evre erken yetişkinlik dönemine denk gelmektedir (Halloway, 2010). Uzamsal düşünmenin soyut bir düşünme biçimi olduğu düşünüldüğünde ve erken yetişkinlik döneminde soyut düşünebilme yeteneği geliştirildiğinden (Biggs ve Collis, 1982) lisans öğrencilerinin 
SOLO modelindeki soyut evrede yer aldığı varsayılmıştır ve çalışma için uygun görülmüştür.

Araştırmanın çalışma grubunu 2012-2013 eğitim-öğretim yılında bir devlet üniversitesinde ilköğretim matematik öğretmenliği programının üçüncü sınıfında öğrenim gören öğretmen adayları oluşturmaktadır. 81 adet öğretmen adayına uygulanan Purdue Uzamsal Görselleştirme (PUGT) Testi sonuçlarına göre belirlenen 6 öğretmen adayıyla klinik mülâkat yapılmıştır. Purdue Uzamsal Görselleştirme Testi (PUGT) sonuçlarına göre üç düzeyde (düşük, orta, yüksek) belirlenen öğrencilerin her birinden ikişer öğrenci seçilmiştir. PUGT'ten alınan toplam puana bakılmıştır. Alınabilecek maksimum ve minimum puan belirlenerek puanlar üç aralığa bölünmüştür. 0-12 puan arasında alanlar kötü, 13-24 puan arasında alanlar orta, 25-36 puan arasında alanlar iyi olarak sınıflandırılmıştır. Seçilen adayların sınıflarını temsil etmesine dikkat edilmiş ve gönüllülük esas alınmıştır.

Verilerin analizi sırasında öğretmen adayları için kullanılan isimler takma isimlerdir. Purdue Uzamsal Görselleştirme Testi'ne göre Merve ve Taner düşük düzeyde, Elif ve Gamze orta düzeyde, Bilal ve Emre ise yüksek düzeydedir. Doğrudan diyaloglara yer verilirken araştırmacının konuşmalarının başında A, katılımcıların söyledikleri cümlelerin başında kullanılan takma isimlerinin ilk harfi kullanılmıştır. 


\section{Veri Toplama Araçları}

Çalışma grubunu oluşturmak için öncelikle 81 adet ilköğretim matematik öğretmen adayına Purdue Uzamsal Görselleştirme Testi (PUGT) uygulanmıştır. Purdue Uzamsal Görselleştirme Testi (Purdue Spatial Visualization Test) 1977 yılında Guay tarafından oluşturulmuştur. Guay tarafından yapılan güvenirlik testi sonuçlarına göre $\mathrm{Ku}$ der-Richardson (KR-20) testin güvenirlik katsayısı 0,87 olarak hesaplanmıştır. Test açılımlar (developments), döndürme (rotations), görünümler (views) olmak üzere üç bölümden oluşmaktadır. Testin kullanıldığı araştırmaların sayısının fazla olması (Baki ve Güven, 2007; Güven ve Kösa, 2008; Hacı̈meroğlu, 2007; Sevimli, 2009; Uygan, 2011) testin araştırmada kullanılma nedenlerinde biridir. 81 kişi ile yapılan bu çalışma için KR-20 güvenirlik analizine göre alfa güvenirlik katsayısı 0.834 olarak bulunmuştur. $0.80 \leq \alpha<1.00$ olduğundan Kalaycı (2010) tarafından belirtildiği üzere ölçek yüksek derecede güvenilirdir. Purdue Uzamsal Görselleştirme testi daha çok görsel bir testtir yönergeler sözel kısımları oluşturmaktadır. Uygan (2011) tarafından bu kısımların Türkçe'ye uyarlanması yapılmıştır, araştırmacı çalışmasında testin güvenirlik katsayısını 0.84 olarak hesaplamıştır.

Klinik mülâkatlarda kullanılmak üzere uzamsal yeteneğin uzamsal görselleştirme becerilerini farklı boyutlar arasında ölçen “Geometri Başarı Testi” araştırmacılar tarafından hazırlanmıştır. Test açık uçlu, çoktan seçmeli ve çizim yapmayı gerektiren sorulardan oluşmaktadır. Ayrıca sorular boyutların kendi içinde ve boyutlar ara- 
sında geçiş yapmayı gerektiren tarzda düzenlenmiştir. Sorulardan iki tanesi iki boyuttan iki boyuta, iki tanesi iki boyuttan üç boyuta, iki tanesi üç boyuttan iki boyuta ve iki tanesi de üç boyuttan üç boyuta geçişi düşünmeyi gerektirmektedir. Geometri Başarı Testi’nde yer

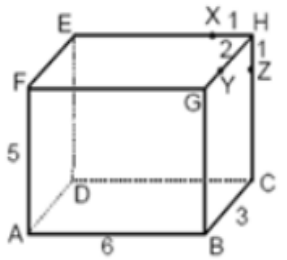

$$
\begin{aligned}
& |\mathrm{AB}|=6 \text { birim } \\
& |\mathrm{BC}|=3 \text { birim } \\
& |\mathrm{AF}|=5 \text { birim } \\
& |\mathrm{HX}|=|\mathrm{HZ}|=1 \text { birim } \\
& |\mathrm{HY}|=2 \text { birim }
\end{aligned}
$$

Yukarıdaki gibi dikdörtgenler prizmas şeklindeki bir kutunun A köşesinden harekete başlayan 3 karıncadan birincisi $\mathrm{X}$, ikincisi $\mathrm{Y}$, üçüncüsü $\mathrm{Z}$ noktasına sirasıyla $\mathrm{x}, \mathrm{y}$ ve $\mathrm{z}$ birim yol alarak ulaşmıştır. Kutunun $\mathrm{ABCD}$ tabanından geçemeyen bu karıncalar $\mathrm{X}, \mathrm{Y}$ ve $\mathrm{Z}$ noktalarına kutu yüzeyinde kalarak en kısa yollardan ulaştıklarına göre, aşağıdaki sıralamalardan hangisi doğrudur?
A) $x<y<z$
B) $x<z<y$
C) $\mathrm{y}<\mathrm{x}<\mathrm{z}$
D) $y<z<x$
E) $z<y<x$

alan sorulara bir örnek aşağıdaki gibidir:

Şekil 1. Geometri başarı testinde yer alan sorulara bir örnek

Şekil 1'deki soru üç boyuttan iki boyuta geçiş gerektiren sorulardan biridir. Kapalı bir şeklin açılımını kullanmayı gerektirdiğinden uzamsal görselleştirme becerisi ile ilgilidir (McGee, 1979). Sorunun çözümü için izlenecek yollardan biri dikdörtgenler prizmasının açılarak iki boyutlu düzleme aktarılmasıdır. Noktalar arasında karşılaştırma yapılırken doğru cevaba ulaşmak için şeklin açılımı yapılmalıdır. Pisagor bağıntısı kullanılarak en kısa yollar hesaplanabilir. Dikkat edilmesi gereken nokta ABCD tabanı kullanılmadan en kısa yolun bulunmaya çalışılacak olmasıdır. 
$\mathrm{Bu}$ sorulara verilen cevapların nasıl analiz edip yorumlayacağ 1 hakkında önceden bilgi vermesi ve araştırmacıya klinik mülâkatlar öncesi yol göstermesi için pilot çalışmanın yapılması uygun görülmüştür. Pilot çalışma için oluşturulan yazılı sınav öncelikle 66 adet dördüncü sınıf ilköğretim matematik öğretmen adayına uygulanmıştır. Pilot çalışma dördüncü sınıflar ile asıl çalışma üçüncü sınıflar ile gerçekleştirildiğinden pilot çalışmaya dâhil olan öğretmen adayları asıl çalışmada yer almamaktadır. Geçerlik ve güvenirlik çalışmaları yapıldıktan sonra klinik mülâkatlarda kullanılmak üzere teste son şekli verilmiştir. Ayrıca pilot çalışma ile elde edilen veriler doğrultusunda her bir seviyeye karşılık gelen yeterliliklere örnekler verilerek problemlerin nasıl değerlendirildiği ile ilgili değerlendirme ölçeği oluşturulmuştur. Şekil 1'deki sorunun değerlendirme ölçeği ile nasıl SOLO düzeylerine yerleştirildiği ile ilgili bilgi verilerin çözümlenmesi kısminda verilmektedir.

Araştırmacılar tarafından geliştirilen “Geometri Başarı Testi”nin görünüş geçerliğini incelemek amacıyla beş uzmanın görüşüne başvurulmuştur. Testteki imlâ ve yazım hataları dönütler doğrultusunda düzeltilmiştir. Farklı anlamalara sebep olabilecek durumlar incelenmiş; soruların veriliş sırası, sayfa yapısı gibi özellikler de gözden geçirilmiştir. Kapsam geçerliğinin sağlanması için yeterli literatür taraması yapılmış ve öğretmen adaylarının uzamsal yeteneklerini ölçebilecek 39 adet açık uçlu ve çoktan seçmeli soru hazırlanmıştır. Sorular yükseköğretime geçiş sınavlarında, ALES, TIMMS ve PISA sınavlarında sorulan sorulardan ve MEB onaylı matematik ders kitaplarında 
ve çeşitli yayınların test kitaplarında yer alan sorulardan oluşturulmuştur. $\mathrm{Bu}$ doğrultuda hazırlanan test için uzman değerlendirme formu beş uzmana verilerek onların görüşleri alınmıştır. Kapsam geçerliği araştırılırken soruların hem uzamsal yeteneğin çalışmada araştırılan uzamsal görselleştirme becerilerini ölçüp ölçmediğine hem de verilen boyutlara uygun olup olmadığına bakılmıştır. Bunun için bir uzman değerlendirme formu oluşturulmuş ve her bir soru için zorluk derecesi, seviyeye uygunluk, soruların ifade edilişi ve soruların belirtilen uzamsal yetenek bileşenlerine göre verilen boyutlara uygun olup olmadığının incelenmesi istenmiştir. Form ektedir. Daha sonra uzman değerlendirme formları incelenerek bazı maddeler tamamen çıkarılmış bazı maddeler ise yeniden düzenlenmiştir. Dönütler doğrultusunda testin kapsam geçerliğini sağladığı sonucuna ulaşılarak teste son şekli verilmiştir. Testin güvenirliği için Miles ve Huberman (1994) tarafından çift-kodlama olarak adlandırılan yöntem kullanılmıştır. Bu amaçla başka bir araştırmacı SOLO modeli hakkında bilgilendirilmiştir. Her bir soruya verilen cevaplara SOLO taksonomisinde karşıllk gelen seviyeye uygun yeterliliklerin yer aldığı değerlendirme ölçeği de verilmiştir. $\mathrm{Bu}$ ölçek ile öğretmen adaylarının verdiği cevapları karşılaştırmış ve en uygun seviyeyi belirlemiştir. Sonrasında araştırmacılar aras1 güvenirlik (intercoder reliability) Miles ve Huberman (1994) tarafından verilen aşağıdaki formül ile belirlenmiştir:

\section{Güvenirlik}

$$
\begin{aligned}
& =\frac{\text { Anlaşılan Durumların Sayısı }}{\text { Anlaşılan Durumların Sayısı }+ \text { Analașılmayan Durumların Sayısı }} \\
& =\frac{92}{92+4}=0,958
\end{aligned}
$$


Miles ve Huberman (1994) bu değerin yüzde 70'in üzerinde olduğu durumlarda güvenilir bir kodlama gerçekleştiğini belirtmiştir. Yürütülen çalışmada bu değer yaklaşık olarak \% 96 olduğundan öğretmen adaylarının uzamsal yeteneklerinin SOLO modeline göre incelendiği bu çalışma için geliştirilen ölçeğin tutarlı ve güvenilir olduğu sonucuna ulaşılmaktadır.

Her bir öğrenci için ortalama 60 dakika süre boyunca klinik mülâkat gerçekleştirilmiştir. Sorulardan iki tanesi iki boyuttan iki boyuta, iki tanesi iki boyuttan üç boyuta, iki tanesi üç boyuttan iki boyuta ve iki tanesi de üç boyuttan üç boyuta düşünmeyi gerektirecek şekilde düzenlenmiştir. Uygulamaya başlamadan önce öğretmen adaylarına bu sınavın bilimsel bir araştırmada kullanılmak üzere yapıldığı, not olarak değerlendirilmeyeceği ve istedikleri şekilde çözebilecekleri vurgulanmıştır. Mülâkatlar sırasında öğrencilere sorular tek tek verilerek soruları cevaplamaları ve çözüme nasıl ulaştıklarını ayrıntılı bir şekilde sesli olarak açıklamaları istenmiştir. Ayrıca "Sence yapıların farklı görünümleri arasında herhangi bir ilişki var mı?”, "Bu soruyla ilgili nasıl bir genelleme yaparsın?”, "Bu genellemeye nasıl ulaştın?", “İstenen dönme hareketi sonunda çıkaracağın sonuç ne olabilir?” şeklinde sorular yöneltilmiştir.

\section{Verilerin Çözümlenmesi}

Klinik mülâkatlar sonunda elde edilen verilerin analizi için ses kayıt cihazına kaydedilen görüşmeler yazılı metin haline dönüştürülmüştür. Araştırmacının kendisinin mülâkatlar sırasında aldığı notlar da ilâve edilmiştir. Görüşmelerden elde edilen öğrenci cevapları pilot 
uygulama sonunda oluşturulan değerlendirme ölçeği yardımıyla SOLO taksonomisine göre hangi düşünme seviyesine girdiği betimsel analiz yapılarak belirlenmiştir. Değerlendirme ölçeği araştırmacılar tarafından oluşturulmuştur. SOLO seviyelerinin her birinin özelliği göz önünde bulundurularak sorulara verdikleri cevaplar örnek alınarak ölçek hazırlanmıştır. İki araştırmacı ile görüş birliğine varılarak oluşturulmuştur. Daha sonrasında hangi sorunun hangi seviyeye girdiği ile ilgili çalışma yapılmıştır.

Araştırmacıların bir cevabı farklı seviyelere yerleştirdiği durumlarda ise en uygun seviyenin ne olabileceği ayrıntılı bir şekilde görüşülüp tartışıldıktan sonra fikir birliğine varılmış ve cevap yerleştirilmiştir.

Pilot uygulama sonunda hazırlanan değerlendirme ölçeğinde yukarıdaki soru için belirlenen yeterlilikler aşağıdaki gibidir: Öğrencilerin cevapları hangi özelliklere sahip olduğu takdirde hangi SOLO düşünme seviyesine gireceği bu şekilde belirlenmiştir.

Örnek soru için Yapı Öncesi (YÖ) seviyede öğrencilerin sorulara verdikleri cevaplar yeterli değildir. Problemin cevaba götürmeyen yönleri sık sık öğrencinin dikkatinin dağılmasına yol açar. Çözüme ulaşırken kullandığı yol onu doğruya götürmez ve daha düşük seviyede bir evreye uygun adımlar atar. Öğrenci soruyu tam olarak anlamadan çözüm üretmeye çalışır. Çözüm için düşünmeden tahminler üzerinden mesafeler arasında karşılaştırmalar yapar. Dikdörtgenler priz- 
masının açık hâlini doğru olarak çizemez ya da çizse bile noktaları yerine yerleştiremez.

Tek Yönlü Yapı (TY) seviyesinde öğrenci probleme odaklanır ancak çözüm için sadece ilişkili bir veriyi kullanır. Kullandığı verinin bütün içindeki yerini ve diğer verilerle ilişkisini anlayamaz. Dolay1sıyla cevapları tutarlı olmayabilir. Öğrenci sorunun tek bir özelliğine odaklanmaktadır. Soruda ABCD tabanının kullanılmaması gerektiği belirtildiği hâlde sadece en kısa yolu bulması gerektiği kısmına odaklanarak tabanı da kullanarak karşılaştırmalar yapmaya gider. Çözüm için şeklin açılımını kullanma yoluna gidebilir ama bu şekilde bir açılımın çözüme katkısını açıklayamaz. Örneğin şekli açtıktan sonra tüm yollara ulaşırken önce köşeye gelir buraya kadar tüm uzaklıklar için mesafeler aynıdır sonra diğer mesafeleri ekleyip sonuca gider. Bu süreçte izlemesi gereken yol hakkında fikir sahibi değildir.

Çok Yönlü Yapı (ÇY) seviyesinde cevaba ulaştıran birden fazla veriyi kullanır ancak bu veriler arasındaki ilişkiyi kavrayamaz. Bu yüzden cevaplarında bazı tutarsızlıklara rastlanabilir. Öğrenci çözüme ulaştıran soruda verilen birden fazla bilgi kullanılır. Hem ABCD tabanını kullanmayacağını hem de en kısa yolu bulması gerektiğini bilir. Ama en kısa yolların hangi yollar olduğunu belirlemede sıkıntılar yaşar. Çok fazla akıl yürütmeden çözmeye başlar. Bulduğu sonucun doğru olup olmadığı konusunda farklı alternatifler düşünerek karşılaştırma yapmaz. 
İlişkisel Yapı (IYY) seviyesinde öğrenci problemin cevabına ulaştıran tüm verileri kullanır ve bunların bütün içindeki yerini ve birbirleriyle olan ilişkilerini anlar. Tutarlı bir yapı oluşturur. Öğrenci sorudan verilen birden fazla bilgiyi ilişkilendirerek cevap verir. Sonuca ulaşt1ran farklı yollar bulmasa da en kısa yolun bu olduğuna dair tatmin edici bir açıklaması vardır. En kısa yolların bulunması için gideceği yolları belirler ve en kısa uzaklığın yine hipotenüs uzunluğu olduğunu düşünerek dik üçgenler oluşturur.

Genişletilmiş Soyut Yapı (GSY) seviyesinde öğrenci çözüme ulaşırken problemde yer alan verilerin ötesinde düşünür ve genellemelere ulaşır. Yeni bir düşünme biçimi oluşturulabilir. Öğrenci tüm olasılıkları göz önüne alarak değerlendirme yapar ve sonuca ulaşır.

İlköğretim matematik öğretmen adaylarının uzamsal görselleştirme becerilerinin iki boyuttan iki boyuta, iki boyuttan üç boyuta, üç boyuttan iki boyuta, üç boyuttan üç boyuta düşünmelerini gerektiren soruları çözerken nasıl düşündüklerini, anlama yollarını, çözüm aşamalarını ortaya koymak için araştırmacı ile adaylar arasında geçen diyaloglardan doğrudan alıntılara yer verilmiştir.

Her bir bölümde sorulan sorulara öğretmen adaylarının verdikleri cevapların betimsel analizi yapılmış ve SOLO modeline göre hangi seviyeye girdikleri belirlenip tablolar oluşturularak genel değerlendirme yapılmıştır. 


\title{
Bulgular
}

$\mathrm{Bu}$ kısımda öğretmen adaylarının "uzamsal görselleştirme" becerilerinin SOLO modeline göre hangi düşünme seviyelerinde olduğu ile ilgili bulgulara yer verilmiştir. Her bir soru için öncelikle öğretmen adaylarının çözüm yolları özetlenmiş doğrudan alıntılara da yer verilerek düşünme seviyeleri belirlenmiştir. Öğretmen adaylarından Elif’in örnek olarak verilen soruya ilişkin çözümü aşağıda sunulmuştur:

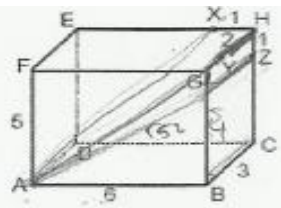
$|A B|=6$ birim
$|\mathrm{BC}|=3$ birim
$|A F|=5$ birim
$[\mathrm{HX}|=| \mathrm{HZ} \mid=1 \mathrm{birim}$
$[\mathrm{HY}]=2$ birim

\begin{abstract}
Yukarıdaki gibi dikdōrtgenler prizması şeklindeki bir kutunun A kōşesinden harekete başlayan 3 karincadan birincisi $X$, ikincisi $Y$, ùçuncusu $Z$ noktasına surasiyla $x, y$ ve $z$ birim yol alarak ulaşmıştır. Kutunun ABCD tabanından geçemeyen bu karıncalar X, Y ve $Z$ noktalarına kutu yüzeyinde kalarak en kısa yollardan ulaģtıklarına göre, aşağıdaki sıralamalardan hangisi doğrudur?
\end{abstract}

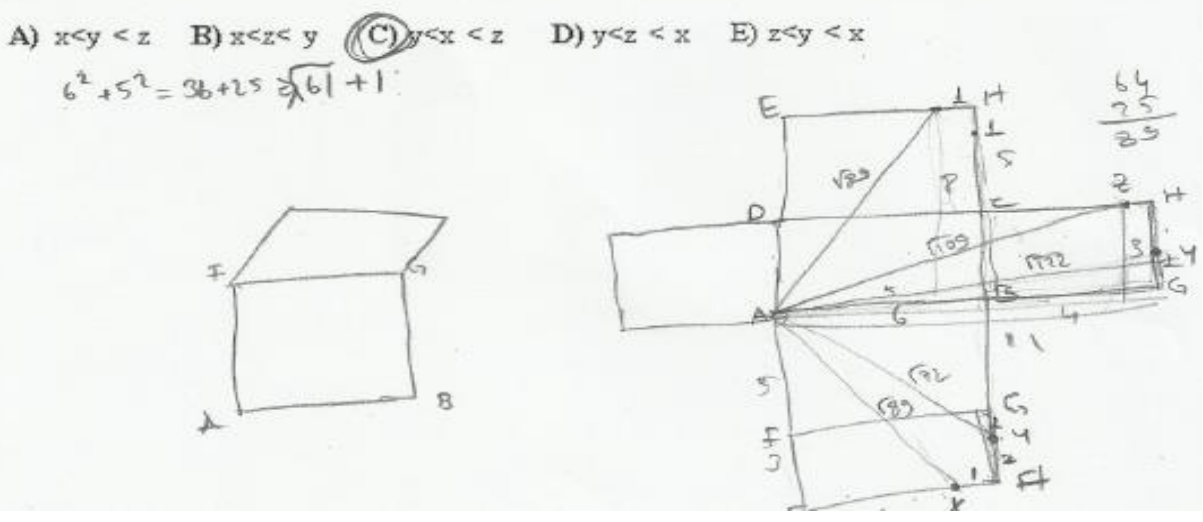

Şekil 2. Elif' in örnek soruya ilişkin çözümü

Problemde $\mathrm{AB}$ ve $\mathrm{CD}$ kenarlarının birleştirilmesi gerektiği ifâde edilmiş olsa da öğretmen adayı $\mathrm{AD}$ ve $\mathrm{BC}$ kenarlarını birleştirmiş dolayısıyla sorunun çözümü için en başta hata yapmıştır. Bu şekilde ke- 
narları birleştirdikten sonra silindiri oluşturmuştur ve $\mathrm{P}$ ve $\mathrm{Q}$ noktalarını yerleştirmiştir. Karıncanın izlediği yolu çizmiştir. Önce çizim üzerinden sağdan sola hareket etmiştir sonra soldan sağa bir yol izlemiş ve bu yolun daha kısa olduğuna karar vermiştir. Sonuç için dikdörtgen üzerinde işaretleme yapıp düşeyde 3 birim, yatayda 2 birim uzunluk alınarak en kısa uzunluk $\sqrt{ } 13$ olarak hesaplamıştır.

Araştırmacı ile arasında geçen diyalog şu şekildedir:

E: Birincisi meselâ A'dan başlayıp buraya geliyor.

A: Dikdörtgenler prizmasının açık şeklini çizer misin?

E: Hıımm... aynısının açık şeklini. Yapamıyorum. Çok kötü. BC bu yüzeyde, 6, 3, 1 birim gitmiş oluyorum. Böyle şurada 1 birim. BHC olursa. A'dan başlayacak ama; şöyle düşünürsem BC'den geçip.4, 36, $16,52 \ldots$

A: Nereyi hesapladın sen şimdi?

E: Şu, şuradan meselâ gittiğinde en kısa yol olur. Direkt açtım, şu açtı̆̆ım yer de BC, CH oluyor şurası da. Şu yan parça. Nereye gidecekti HC arasindan 1 birim şuraya.

A: Diğer türlü nereyi düşündün?

E: O zaman 6 birim, yükseklik 5 birimdi.4 birim şurası 3 birim. 10, 10, 9.

A: Bu hangi noktaya ulaşırken izlediğin yol?

E: $Z$

A: Z noktasına ulaşırken 10, 9. 
E: Nereye ulaşacak, oradan HGF mi? Şuradan 2 birim. Şöyle bir şey burasi toplamda 11. Burada 1, 1 birim var.121, 122, bu neydi?

A: Hangi noktaydr?

E: İkisi de HE üzerinde. HE üzerinde şöyle bir nokta. 1, o zaman 5 birim alttan burası kaçtı HC 5 birim. 3 birim, 8. 8'in karesi 64. Ama aslinda...

A: Şuradakilerden niye vazgeçtin sonra?

E: Buradan sonra buraya geçtim. Oradan hesaplayalım 5, 3 yine aynı. 5 burada 6, 6. Daha küçük çıkıyor. Sanki burada daha yakın.

A: Buradan daha yakın gibi mi geldi sana?

E: Diğgerinde öyle gibi geldi ama şu an. Hayır, eşit çıkmıyor. y burada daha küçük.

A: Şekli açtığında $x, y, z$ noktalarını yerleştirdin, onların yerlerinin sabit olmasl gerekmez mi? Bir burada allyorsun bir burada alıyorsun farklı farkll.

E: Ama doğru değil mi mesela kapattı̆̆ımızda şu arka tarafı. Şunlar yan tarafları, şu ön. O zaman şu yan tarafina baktığımızda BC, GH. Buranın kenarı da oranın orta noktası. O yüzden eşit oluyor. Hani o yüzden iki tane yerde çıkıyor.

A: Tamam. Ama o zaman ikisi de aynı noktadaysa ĕger, nasıl birbirinden farklı uzaklıklar çıkıyor?

E: Isşte onu bilmiyorum. y daha yakın çıkıyordu.

En kısa yolların hangi yollar olduğunu belirlemede güçlük yaşadığı için ve bulduğu sonucun doğru olup olmadığı konusunda farklı alternatifler düşünerek karşılaştırma yapmayıp sezgisel yaklaştığı için 
Elif “Çok Yönlü Yapı (ÇY)" seviyesindedir. Yukarıdaki diyalogda koyu olarak yazılan kısımda bu durum görülmektedir.

Elif'in cevabının değerlendirmesine benzer şekilde her bir öğrencinin cevapları değerlendirilip uygun SOLO düşünme seviyelerine yerleştirildikten sonra aşağıdaki tablo oluşturulmuştur.

Tablo 1. İlköğretim Matematik Öğretmen Adaylarının Düzeylerine Göre Uzamsal Görselleştirme Becerileri

\begin{tabular}{cccccccccc}
\hline \multicolumn{10}{c}{ Uzamsal Görselleştirme Becerileri } \\
\hline \multirow{2}{*}{ Düşük } & \multicolumn{1}{c}{1} & 2 & 3 & 4 & 5 & 6 & 7 & 8 \\
\cline { 2 - 10 } & Merve & TY & YÖ & TY & TY & TY & TY & TY & ÇY \\
\cline { 2 - 9 } & Taner & TY & TY & TY & ÇY & ÇY & TY & IY & ÇY \\
\cline { 2 - 9 } Orta & Elif & ÇY & TY & ÇY & ÇY & TY & TY & ÇY & IY \\
\cline { 2 - 9 } & Gamze & TY & TY & ÇY & ÇY & IY & ÇY & ÇY & IY \\
\hline \multirow{2}{*}{ Yüksek } & Bilal & IY & IY & ÇY & GSY & IY & ÇY & GSY & ÇY \\
\cline { 2 - 9 } & Emre & IY & TY & ÇY & ÇY & Ç.Y & ÇY & IY & ÇY \\
\hline
\end{tabular}

Tablo 1 ile uzamsal görselleştirme becerileri ile ilgili olarak öğretmen adaylarının her bir soruya verdikleri cevapların seviyesi özetlenmiştir. Tablo ayrıca öğretmen adaylarının cevaplarının seviyesini Purdue Uzamsal Görselleştirme Testi’ne göre yer aldıkları üç farklı seviyeye göre de inceleme ve yorumlama firsatı vermiştir.

Düşük düzeyde uzamsal görselleştirme becerisine sahip Merve, sekiz sorunun altısına tek yönlü yapı seviyesinde, bir soruya yapı öncesi seviyede ve bir soruya da çok yönlü yapı seviyesinde cevap vermiştir. Aynı düzeydeki Taner'in cevaplarının dördü tek yönlü yapı seviyesinde, üçü çok yönlü yapı seviyesinde ve biri de ilişkisel yapı 
seviyesindedir. Buradan düşük seviyede olan öğretmen adaylarının cevaplarının çoğunlukla tek yönlü yapı seviyesinde olduğu sonucu çıkmaktadır.

Orta düzeyde uzamsal görselleştirme becerisine sahip öğretmen adaylarına bakıldığında Elif, sekiz sorunun dördünde çok yönlü yapı, üçünde tek yönlü yap1 ve birisinde ilişkisel yapı seviyesindedir. Gamze'nin cevaplarının dördü çok yönlü yapı, ikisi tek yönlü yapı ve diğer ikisi de ilişkisel yapı seviyesindedir. Dolayısıyla orta seviyede öğretmen adaylarının cevapları çoğunlukla çok yönlü yapı seviyesinde yer almaktadır.

Yüksek düzeyde uzamsal görselleştirme becerisine sahip öğretmen adaylarından Bilal'in cevaplarından üçü çok yönlü yapı, üçü ilişkisel ve ikisi de genişletilmiş soyut yapı seviyesindedir. Emre'nin cevaplarından biri tek yönlü yapı, beşi çok yönlü yapı ve ikisi ilişkisel yapı seviyesindedir. Bu bilgiler 1şı̆̆ında yüksek seviyede öğretmen adaylarının da çok yönlü yapı seviyesinde olduğu bulgusuna ulaşılmiștır.

Tablo 2. 2B-2B Uzamsal Görselleştirme Becerilerinin Genel Değerlendirilmesi

\section{B-2B Uzamsal Görselleştirme}

\begin{tabular}{ccccc}
\hline YÖ & TY & ÇY & IY & GSY \\
\hline 0 & 1 & 6 & 4 & 1 \\
\hline
\end{tabular}

İki boyuttan iki boyuta düşünme gerektiren iki soru için 6 öğretmen adayının verdiği toplam 12 cevap değerlendirilmiştir. Öğretmen adaylarının cevaplarının 1'i tek yönlü yapı seviyesinde, 6'sı çok 
yönlü yapı seviyesinde, 4'ü ilişkisel yapı seviyesinde, 1'i genişletilmiş soyut yapı seviyesinde olup yapı öncesi seviyede cevap bulunmamaktadir.

Tablo 3. 2B-3B Uzamsal Görselleştirme Becerilerinin Genel Değerlendirilmesi

\begin{tabular}{ccccc}
\hline \multicolumn{5}{c}{ 2B-3B Uzamsal Görselleştirme } \\
\hline YÖ & TY & ÇY & IY & GSY \\
\hline 0 & 4 & 5 & 2 & 1 \\
\hline
\end{tabular}

İki boyuttan üç boyuta düşünme gerektiren iki soru için 6 öğretmen adayının verdiği toplam 12 cevap değerlendirilmiştir. Öğretmen adaylarının cevaplarının 4'ü tek yönlü yapı seviyesinde, 5'i çok yönlü yapı seviyesinde, 2'si ilişkisel yapı seviyesinde, 1'i genişletilmiş yapı seviyesinde olup, yapı öncesi seviyede birey bulunmamaktadir.

Tablo 0. 3B-2B Uzamsal Görselleştirme Becerilerinin Seviyelerinin Genel Değerlendirilmesi

\begin{tabular}{ccccc}
\hline \multicolumn{5}{c}{ 3B-2B Uzamsal Görselleştirme } \\
\hline YÖ & TY & ÇY & IY & GSY \\
\hline 1 & 6 & 4 & 1 & 0 \\
\hline
\end{tabular}

Üç boyuttan iki boyuta düşünme gerektiren iki soru için 6 öğretmen adayının verdiği toplam 12 cevap değerlendirilmiştir. Öğretmen adaylarının cevaplarının 1'i yapı öncesi seviyesinde, 6's1 tek yönlü yapı seviyesinde, 4'ü çok yönlü yapı seviyesinde, 1'i ilişkisel yapı seviyesinde olup, genişletilmiş yapı seviyesinde birey bulunmamaktadır. 
Tablo 5. 3B-3B Uzamsal Görselleştirme Becerilerinin Genel

Değerlendirilmesi

\begin{tabular}{ccccc}
\hline \multicolumn{5}{c}{ 3B-3B Uzamsal Görselleştirme } \\
\hline YÖ & TY & ÇY & İY & GSY \\
\hline 0 & 5 & 5 & 2 & 0 \\
\hline
\end{tabular}

Üç boyuttan üç boyuta düşünme gerektiren iki soru için 6 öğretmen adayının verdiği toplam 12 cevap değerlendirilmiştir. Öğretmen adaylarının 5'i tek yönlü yapı seviyesinde, 5'i çok yönlü yapı seviyesinde, 2'si ilişkisel yapı seviyesinde olup, genişletilmiş yapı seviyesinde ve yapı öncesi seviyede birey bulunmamaktadır.

Tablo 6. Öğretmen Adaylarının Uzamsal Görselleştirme Becerilerinin Genel Değerlendirilmesi

\begin{tabular}{ccccc}
\hline \multicolumn{5}{l}{ Uzamsal Görselleştirme Becerileri } \\
\hline YÖ & TY & ÇY & IY & GSY \\
\hline 1 & 16 & 20 & 9 & 2 \\
\hline
\end{tabular}

Altı adet ilköğretim matematik öğretmen adayının her birinden alınan sekiz soru ile toplam 48 sorudan biri yapı öncesi seviyede, on altıs1 tek yönlü yap1 seviyesinde, yirmisi çok yönlü yap1 seviyesinde, dokuzu ilişkisel yapı seviyesinde, ikisi genişletilmiş soyut yapı seviyesindedir. Dolayısıyla öğretmen adaylarının uzamsal görselleştirme becerileri SOLO modelinin düşünme evrelerine göre ağırlıklı olarak Çok Yönlü Yapı (ÇY) seviyesindedir.

\section{Tartışma}

İlköğretim matematik öğretmen adaylarının uzamsal görselleştirme becerileri SOLO modelinin düşünme seviyelerine göre incelen- 
dikten sonra elde edilen sonuçlar literatürde yer alan çalışmalarla karşılaştırılmış, benzerlikler ve farklılıklar araştırılmıştır. Hem SOLO modeli kullanılarak yapılan çalışmalarla hem de uzamsal yetenek ile ilgili yapılan çalışmalarla kıyaslama yapılmıştır.

Klinik mülâkatlar sonucu elde edilen verilere göre öğretmen adayları uzamsal görselleştirme becerileri açısından SOLO modelinin düşünme evrelerine göre ağırlıklı olarak Çok Yönlü Yapı (ÇY) seviyesindedir. Buna göre öğretmen adayları cevaba ulaşırken birden fazla veriyi kullanmaktadır; ancak bu veriler arasındaki ilişkiyi kavrayamamaktadırlar. Bu yüzden cevaplarında bazı tutarsızlıklara rastlanmaktadır. Pegg ve Davey (1998), Çelik (2007) de çalışmalarında benzer sonuçlara ulaşmıştır. Lian ve İdris'in (2006) çalışmasında katılımcıların çoğunlukla tek yönlü yapı ve çok yönlü yapı seviyesinde olması ile çalışmanın bu kısmında öğretmen adaylarının cevaplarının seviyeleri benzerlik göstermektedir. Çelik (2007) çalışmasına katılan kişilerin cevaplarının ilişkisel yapı seviyesinin altında kalması çalışmanın bu kısmında elde edilen sonuçlarla paralellik göstermektedir. Çelik (2007) bu durumu öğretmen adaylarının bilgi ve becerilerini tutarlı bir şekilde bütünleştirememelerine bağlamıştır.

Öğretmen adaylarının uzamsal görselleştirme seviyelerine göre incelediğimizde düşük düzeyde uzamsal görselleştirme becerisine sahip olanlar çoğunlukla tek yönlü yapı seviyesinde olduğundan probleme odaklanmaktadırlar; ancak çözüm için sadece ilişkili tek bir veriyi kullanmaktadırlar. Kullandığı verinin bütün içindeki yerini ve diğer verilerle ilişkisini anlayamamaktadırlar. Hattie ve Brown'a 
(2004) göre tek yapılı düzeyde verilen cevaplar derinlemesine olmadığgndan düşük düzeydeki öğretmen adaylarının yüzeysel bir öğrenmeye sahip olduğu söylenebilir. Dolayısıyla düşük seviyede uzamsal görselleştirme yeteneğine sahip öğrencilerin tek yönlü yap1 seviyesinde olması beklenen bir durumdur, diyebiliriz.

Orta düzeyde uzamsal görselleştirme becerisine sahip öğretmen adaylarına bakıldığında ise cevapları çoğunlukla çok yönlü yapı seviyesinde yer almaktadır. Uzamsal görselleştirme becerisi artınca öğretmen adaylarının cevaplarının seviyesi de bir seviye ilerlemiştir, bu olması gereken bir durum olarak düşünülebilir; çünkü öğrencilerin düzeyi arttıkça verecekleri cevapların daha ileri bir düzeyde olması beklenmektedir.

Benzer şekilde yüksek seviyede öğretmen adaylarının da çok yönlü yapı seviyesinde olduğu bulgusuna ulaşılmıştır. Ancak farklı olarak yüksek düzeyde uzamsal görselleştirme becerisine sahip öğretmen adaylarından Bilal'in cevaplarının üçünün ilişkisel ve ikisinin de genişletilmiş soyut yapı seviyesinde olması yine de daha ileri bir seviyede olduklarını gösterebilir. Bu bilgiler 1şığında orta ve yüksek düzeydeki öğretmen adayları genel olarak problemlerde verilen birden fazla bilgiyi kullanmışlar; fakat bunların bütün içindeki yerini ve birbirleriyle ilişkilerini tam olarak anlayamamışlardır ve her üç durumda da öğretmen adaylarının bilgilerinin yine yüzeysel olduğu görülmektedir. 
Boyutlara göre inceleme yapıldığında elde edilen bulgular doğrultusunda boyut seviyesi arttıkça öğretmen adaylarının cevaplarının seviyesi SOLO taksonomisine göre düşmektedir. İki boyuttan iki boyuta ve iki boyuttan üç boyuta geçiş gerektiren sorularda verilen cevaplar Çok Yönlü Yapı seviyesindedir ve Genişletilmiş Soyut Yapı seviyesinde cevaplara rastlanmaktadır. Ancak üç boyuttan iki boyuta ve üç boyuttan üç boyuta geçiş gerektiren sorularda cevaplar Tek Yönlü Yapı seviyesindedir ve Genişletilmiş Soyut Yapı seviyesinde cevaplara rastlanmamaktadır. Soyut düşünme gerektiren durumlarda cevapların seviyesi düşmektedir, diyebiliriz. Buradan uzamsal yeteneğin geliştirilmesi için çeşitli faaliyetlerin yapılmasının gerekliliği ortaya çıkmaktadır.

\section{Sonuç}

Çalışmanın giriş kısmında uzamsal yeteneğin sadece matematikte değil hayatımızın her alanında önemli bir yere sahip olduğu konusu üzerinde durulmuştur. Bu durumda hayatımızda bu kadar önem taşıyan bir konuda etkili bir öğretim yapılması önem arz etmektedir. Öğrencilerin uzamsal yeteneklerinin geliştirilmesine yönelik öğretim yapabilmeleri için öğretmenlerin kendilerinin uzamsal yeteneklerinin yeterli düzeyde hatta yüksek düzeyde olması gereklidir. Bu yüzden öğretmen yetiştirme sırasında verilecek eğitimin kritik bir değere sahip olduğu su götürmez bir gerçektir. Öğretmen adaylarının lisans döneminde eksikliklerin giderilmesi için durum tespitinin yapılması önem arz etmektedir. Öğrenciler lisans eğitimlerine girdikleri tek bir sınav ile başlamaktadır ve bu sınav da onların diğer yeteneklerini de ölçmediği gibi 
uzamsal yeteneklerini de tam olarak ölçmemektedir. Bu çalışma ile alternatif bir yöntem olarak ve farklı bir bakış açısı getirmesi için öğretmenler tarafindan da kullanılabilir.

Uzay geometri konusu daha çok ortaöğretim konusu olmasına rağmen öğrenciler lisansa başladıklarında da pek çok eksikleri vardır. Uzay geometri daha çok üst düzey soyut kavramları içerdiğinden yapılan önerilerin göz önünde bulundurulması faydalı olabilir. Dinamik geometri programlarının, somut materyallerin kullanımının bu aşamada etkili olabileceğini gösteren çalışmalar bulunmaktadır. Nitekim Baki ve Güven (2007), Kösa (2011), Uygan (2011) dinamik geometrinin; Arıcı (2012)'da origaminin uzamsal yeteneğin gelişmesinde etkili olduğunu çalışmalarında göstermişlerdir.

Öğretmen adaylarının ya da öğrencilerin geometrik düşünme seviyelerinin belirlenmesinde daha çok düzlem geometride düşünme düzeylerini araştıran çalışmalar yer almaktadır. Uzay geometri konusunda öğrencilerin düşünme seviyelerini belirleyen çalışmalar az sayıdadır. Bu çalışmada uzay geometride uzamsal yeteneğin uzamsal görselleştirme bileşeni ele alınarak değerlendirme yapılmıştır. Uzamsal yeteneğin diğer araştırmacılar tarafından belirlenen farklı bileşenleri ya da uzay geometri de yer alan başka konular üzerinden gidilerek öğrencilerin cevap seviyeleri belirlenebilir.

$\mathrm{Bu}$ çalışmada elde edilen veriler SOLO modelinin düşünme seviyelerine göre analiz edilmiştir. Aynı veriler başka bir taksonomi ile değerlendirilip iki model arasında karşılaştırma yapılabilir böylelikle 
farklı bir bakış açısıyla da ele alınmış olur. Bu şekilde eksik kalan, gözden kaçırılan yönler varsa eklemeler yapılabilir. SOLO modeli öğrencileri bireysel olarak bir sınıfa yerleştirmek yerine onların mevcut durumda verdikleri cevapları sınıflandırdığından alternatif bir değerlendirme yöntemi kullanmak isteyen araştırmacılara önerilebilir.

Araştırma için uzamsal görselleştirme becerisi ile ilgili 8 adet soru sorulmuştur. Ayrıca boyutların (iki boyuttan iki boyuta, iki boyuttan üç boyuta, üç boyuttan iki boyuta, üç boyuttan üç boyuta) her birinden ikişer soru sorularak değerlendirme yapılmıştır. Bu çalışmada klinik mülâkat yöntemi kullanıldığından yer alan soru sayısı az olmamakla birlikte soru sayısı artırılarak öğrencilerin belirlenen uzamsal yetenek bileşeninde ve belirlenen boyutlarda daha belirgin sonuçlar elde edilebilir. Başka bir yol olarak Çelik (2007), Burnett (1999), Rider (2004) çalışmalarında bazı sorular için öğrencilerin verdikleri cevap seviyelerinin başına zayıf ya da güçlü ekleyerek daha hassas değerlendirme yapma yoluna gitmiştir. Her bir seviye için yeterlilikler belirlenirken zayıf ve güçlü olma durumlarında beklenen özellikler de eklenebilir.

Araştırma 6 adet ilköğretim matematik öğretmen adayı ile gerçekleştirilmiştir. Daha çok öğrenci ile ya da daha farklı branşlardaki öğretmen adaylarıyla ya da hizmet içinde yer alan öğretmenlerle çalış1labilir. Daha sonra elde edilen veriler kıyaslanabilir ve böylelikle mevcut çalışmayı geliştirme yönünde katkı sağlanabilir. 
Uzamsal yeteneğin geliştirilmesi konusunda teknolojik desteğin ya da somut materyal kullanımının olumlu yönde etkili olduğu konusunda çok sayıda akademik çalışma yapılmıştır ve yapılmaya devam etmektedir. Bu çalışmada öğretmen adaylarının uzamsal görselleştirme becerilerini belirlenmesi konusunda durum tespiti yapılmıştır. Öğretmen adaylarının seviyeleri göz önüne alındığında daha da geliştirilmesi için alternatif yöntemlere, materyallere, çalışma yapraklarına, origami gibi etkinliklere lisans seviyelerinde yer verilebilir. Bilgisayar destekli matematik öğretimi, matematik ve sanat, matematik ve origami gibi derslerin yanında başka derslerin de seçmeli ders olarak alınmasına firsat tanınmalıdır.

\section{Kaynakça}

Accascina, G. ve Rogora, E. (2006). Using Cabri 3D diagrams for teaching geometry, achievement, spatial visualization and affective factors. American Educational Research Journal, 14, 51-77.

Altun, M. (2009). Matematik öğretimi. Bursa: Alfa Yayınevi.

Ardıç, E. Ö., Yılmaz, B. ve Demir, E. (2012). İlköğretim 8. sınıf öğrencilerinin merkezi eğilim ve yayılım ölçüleri hakkındaki istatistiksel okuryazarlık düzeylerinin solo taksonomisine göre incelenmesi. X. Fen Bilimleri ve Matematik Eğitimi Kongresi, Niğde, Türkiye, (27-30 Haziran).

Ar1c1, S. (2012). The effect of origami-based instruction on spatial visualization, geometry achievement and geometric reasoning of tenth-grade students. Yayımlanmamış yüksek lisans tezi, Boğaziçi Üniversitesi.

Baki A. ve Güven B. (2007). Dinamik geometri yazılımı Cabri 3D’nin 
öğretmen adaylarının uzamsal yetenekleri üzerine etkisi. The Proceedings of 7th International Educational Technology Conference, 116-120. Near East University, Kuzey Kıbrıs Türk Cumhuriyeti.

Baki, A. (2008). Kuramdan uygulamaya matematik eğitimi. Ankara: Harf Eğitim.

Bako, M. (2003). Different projecting methods in teaching spatial geometry. 24.10.2012,

http://www.dm.unipi.it/ didattica/CERME3/proceedings/Group s/TG7/TG7_Bako cerme3.pdf.

Battista, M., Wheatley, G. ve Talsma, G. (1989). Spatial visualization, formal reasoning, and geometric problem-solving strategies of preservice elementary teachers. Focus on Learning Problems in Mathematics, 11(4), 17-30.

Biggs, J. B. ve Collis, K. F. (1982). Evaluating the quality of learning: The SOLO taxonomy. New York: Academic Press.

Biggs, J. B. ve Collis, K. F. (1991). Multimodal learning and the quality of intelligent behavior. H. Rowe, (Ed.), Intelligence: Reconceptualization and measurement içinde (57-76). New Jersey: Lawrence Erlbaum Assoc.

Boz, N. ve Boz, Y. (2006). Do prospective teachers get enough experience in school placements? Journal of Education for Teaching, 32(4), 353-368.

Burnet, S. A. ve Lane, D. M. (1980). Effects of academic instruction on spatial visualization. Intelligence, 4(3), 233-242.

Burnett, P. C. (1999). Assessing the outcomes of counseling within a learning framework. Paper presented at the annual conference of the American Educational Research Association, Montreal, 
Canada.

Clements, D. H. (1998). Geometric and spatial thinking in young children (Report no. NSF-MDR-8954664). Arlington, VA: NATIONAL Science Foundation. (ERIC No. ED436232).

Clements, D. H. ve Battista, M. T. (1992). Geometry and spatial reasoning. D. A. Grouws (Ed.), Handbook of research on mathematics teaching and learning içinde (420-464). Toronto: Macmillan.

Creswell, J. W. (1998). Qualitative inquiry and research design: Choosing among five traditions. London: Sage Publications.

Crowley, L. (1987). The van Hiele model of the development of geometric thought. M. M. Lindquistand ve A. P. Shulte, (Ed.), Learning teaching geometry, $K-12$, içinde (1-16). Reston: NCTM.

Çelik, D. (2007). Öğretmen adaylarının cebirsel düşünme becerilerinin analitik incelenmesi. Yayımlanmamış doktora tezi, Karadeniz Teknik Üniversitesi Fen Bilimleri Enstitüsü.

Çelik, D. ve Baki, A. (2007). Öğretmen Adaylarının Cebirde Çoklu Gösterimlerden Yararlanma Durumları Üzerine Bir Çalışma. $7^{\text {th }}$ International Educational Technology Conference, Near East University, Lefkoşe, Kuzey Kıbrıs Türk Cumhuriyeti.

Çepni, S. (2010). Araştırma ve proje çalışmalarına giriş (5. baskı). Trabzon: Celepler Matbaacilik.

Dindyal, J. (2003). Algebraic thinking in geometry at high school level. Yayımlanmamış doktora tezi, Illinois State University.

Duatepe, A. (2000). An investigation on the relationship between van Hiele geometric level of thinking and demographic variables for pre-service elementary school teachers. Yayımlanmamış yüksek 
lisans tezi, Ortadoğu Teknik Üniversitesi.

Dursun, Ö. (2010). The relationships among preservice teachers' spatial visualization ability, geometry self-efficacy, and spatial anxiety. Yayımlanmamış doktora tezi, Ortadoğu Teknik Üniversitesi.

D'Oliveira, T. C. (2004). Dynamic spatial ability: An exploratory analysis and a confirmatory study. The International Journal of Aviation Psychology, 14(1), 19-38.

Fennema, E. ve Loef, F. M. (1992). Teachers' knowledge and its impact. D. A. Grouws, (Ed.), Handbook of research on mathematics teaching and learning içinde (147-164). NewYork: Macmillan.

French, D. (2004). Teaching and learning geometry. London: Continuum International Publishing Group.

Gökbulut, Y., Sidekli, S. ve Yangın, S. (2010). Sınıf öğretmeni adaylarının van Hiele geometrik düşünce düzeylerinin bazı değişkenlere (lise türü, lise alanı, lise ortalaması, ÖSS puanları, lisans ortalamaları ve cinsiyet) göre incelenmesi. Türk Ĕ̆itim Bilimleri Dergisi, 8(2), 375-396.

Goldin, G. A. (1998). Observing Mathematical Problem Solving Through Task-Based Interviews. A. R. Teppo, (Ed.), Qualitative Research Methods in Mathematics Education içinde (40-62). Reston, Virginia: National Council of Teachers of Mathematics.

Groth, R. E. (2002). Characterizing secondary students' understanding of measures of central tendency and variation. XXIV PME-NA, Athens Georgia, Bildiriler Kitabı, 1, 247-259.

Groth, R. E. ve Bergner, J. A. (2006). Preservice elementary teachers' conceptual and procedural knowledge of mean, median and 
mode. Mathematical Thinking and Learning, 8(1), 37-63.

Guillen, G. (1996). Identification of van Hiele levels of reasoning in three-dimensional geometry. Proceedings of the 20th Conference of the International Group for the Psychology of Mathematics Education, 1, 43-50.

Gutierrez, A., Pegg, J. ve Lawrie, C. (2004). Characterization of students' reasoning and proof abilities in 3-dimensional geometry. Proceedings of the 28th Conference of the International Group for the Psychology of Mathematics Education, 2, 511-518.

Güven, B. (2006). Öğretmen adaylarının küresel geometri anlama düzeylerinin karakterize edilmesi. Yayımlanmamış doktora tezi, Karadeniz Teknik Üniversitesi, Fen Bilimleri Enstitüsü.

Güven, B. ve Kösa, T. (2008). The effect of dynamic geometry software on student mathematics teachers' spatial visualization skills. The Turkish Online Journal of Educational Technology, 7(4), 100-107.

Haciömeroglu, S. E. (2007). Calculus students' understanding of derivative graphs: Problems of representations in calculus. Yayımlanmamış doktora tezi, The Florida State University.

Halat, E. (2006). Sex-related differences in the acquisition of the van Hiele levels and motivation in learning geometry. Asia Pacific Education Review, 7(2), 173-183.

Halloway, W. (2010). Quality learning with reference to the solo model. 12.10.2012, http://www.une.edu.au/education/research/bhutan/publications/b hutan-solo-halloway.pdf.

Han, H. (2007). Middle school students' quadrilateral learning: a comparison study. Yayımlanmamış doktora tezi, University of 
Minnesota, The Faculty of the Graduate School.

Hattie, J. A. C. ve Brown, G. T. L. (2004). Cognitive Processes in asTTle: The SOLO Taxonomy. AsTTle Technical Report 43, University of Auckland, Ministry of Education.

Hoover, C. L. (1996). Model for Characterizing and Creating Certificate Programs in Technology Specific Areas. Carnegie Mellon University, Pittsburgh, PA.

Hvizdo, M. M. (1992). A study of the effect of spatial ability on geometry grades. Yayımlanmamış yüksek lisans tezi, Southern Connecticut State University, Connecticut.

Jones, G. A., Langrall, C. W, Thornton, C. A. ve Mogill, A. T. (1997). A framework for assessing and nurturing young children's thinking in probability. Educational Studies in Mathematics, 32, 101-125.

Jones, G. A., Thornton C. A., Langrall, C. W., Mooney, E. S., Perry, B. ve Putt, I. J. (2000). A framework for characterizing children's statistical thinking. Mathematical Thinking and Learning, 2(4), 269-307.

Jones, K. (2000). Providing a foundation for deductive reasoning: Students' interpretations when using dynamic geometry software and their evolving mathematical explanations. Educational Studies in Mathematics, 44 (1-2), 55-85.

Jurdak, M. (1991). Van Hiele levels and the SOLO taxonomy. International Journal of Mathematical Education in Science and Technology, 22(1), 57-60.

Kahan, J. A., Cooper, D. A. ve Bethea, K. A. (2003). The role of mathematics teachers' content knowledge in their teaching: A framework for research applied to a study of student teachers. $\mathrm{Jo}_{o}$ 
urnal of Mathematics Teacher Education, 6, 223-252.

Kalaycı, Ş. (2010). SPSS uygulamalı çok değişkenli istatistik teknikleri (5. bask1). Ankara: Asil Yayınları.

Kılıç, Ç. (2003). İlköğretim 5. sınıf matematik dersinde van Hiele düzeylerine göre yapllan geometri ögrretiminin ögrrencilerin akademik başarıları, tutumları ve hatırda tutma düzeyleri üzerindeki etkisi. Yayımlanmamış yüksek lisans tezi, Anadolu Üniversitesi, Eğitim Bilimler Enstitüsü.

Koç, Y., Işıksal, M., Osmanoğlu, A., Çetinkaya, B., Aşkun, C. S., Bulut, S., Sevis, Ş. ve Esen, Y. (2011). Solo modeli ile uzamsal görselleştirme becerilerinin ölçülmesi. 10. Matematik Sempozyити, İstanbul, Türkiye, (21-23 Eylül).

Kösa, T. (2011). Ortaöğretim öğrencilerinin uzamsal becerilerinin incelenmesi. Yayımlanmamış doktora tezi. Karadeniz Teknik Üniversitesi Eğitim Bilimleri Enstitüsü.

Lam, P. ve Foong, Y. (1996). Rasch analysis of math SOLO taxonomy levels using hierarchical items in testlets, ERIC-ED 398271.

Lian, L. H. ve İdris, N. (2006). Assessing algebraic solving ability of form four students. International Electronic Journal of Mathematics Education (IEJME), 1(1), 55-76.

Lloyd, G. M. ve Wilson, M. (1998). Supporting innovation: The impact of a teacher's conception of function on his implementation of a reform curriculum. Journal for Research in Mathematics Education, 29(3), 248-274.

McGee, M. G. (1979). Human spatial abilities: Psychometric studies and environmental, genetic, hormonal and neurological influences. Psychological Bulletin 86, 889-918. 
MEB, (2002). Öğretmen yeterlilikleri. Ankara: Milli Eğitim Basımevi.

MEB, (2009a). Matematik dersi (1-5. sınıflar) öğretim programı, Ankara.

MEB, (2009b). Matematik dersi (6-8. sinıflar) ögretim programı, Ankara.

MEB, (2012a). Matematik uygulamaları dersi (5, 6, 7 ve 8. sinuflar) ögretim programı, Ankara.

MEB, (2012b). Zekâ oyunları dersi (5, 6, 7 ve 8. sinıflar) öğretim programi, Ankara.

Merriam, S. B. (1998). Qualitative Research and Case Study Applications in Education. Revised and Expanded from "Case Study Research in Education.". Jossey-Bass Publishers, 350 Sansome St, San Francisco, CA 94104.

Miles, M. B. ve Huberman, A. M. (1994). Qualitative data analysis: A sourcebook of new methods. California: SAGE publications Inc.

Money, E. S. (2002). A framework for characterizing middle school students' statistical thinking. Mathematical Thinking and Learning, (4)1, 23-63.

NCTM, (2000). Principles and standards for school mathematics. Reston, VA: National Council of Teachers of Mathematics.

Olkun, S. (2003). Making connections: improving spatial abilities with engineering drawing activities. International Journal for Mathematics Teaching and Learning. 18 Mayı 2012, http://www.cimt.plymouth.ac.uk/journal/default.html.

Olkun, S. ve Altun, A. (2003). İlköğretim öğrencilerinin bilgisayar deneyimleri ile uzamsal düşünme ve geometri başarıları arasın- 
daki ilişki. Turkish Online Journal of Educational Technology, 2 (4), 86-91.

Pegg, J. ve Coady, C. (1993). Identifying SOLO levels in the formal Mode. InProceedings of the 17th International Conference for the Psychology of Mathematics Education içinde, 1, 212-219.

Pegg, J. ve Davey, G. (1998). Interpreting student understanding in geometry: A synthesis of two models. R. Lehrer ve D. Chazen, (Ed.), Designing learning environments for developing understanding of geometry and space içinde (109-135). New Jersey: Lawrence Erlbaum Associates.

Pegg, J. ve Tall, D. (2004). Fundamental cycles in learning algebra: An analysis. 10 Haziran 2012, http://www.warwick.ac.uk/staff/David.Tall/drafts/dot2001z-peg g-icmi-algebra.pdf

Rider, R. L. (2004). The effect of multi-representational methods on students' knowledge of function concepts in developmental college mathematics. Yayınlanmamış doktora tezi, Graduate Faculty of North Carolina State University.

Sevimli, E. (2009). Matematik öğretmen adaylarının belirli integral konusundaki temsil tercihlerinin uzamsal yetenek ve akademik başarı bağlamında incelenmesi. Yayımlanmamış yüksek lisans tezi, Marmara Üniversitesi Eğitim Bilimleri Enstitüsü.

Sherard, W. H. (1981). Why is geometry a basic skill? Greenville: Furman University.

Shulman, L. S. (1986). Those who understand: Knowledge growth in teaching. Educational Researcher, 15(2), 4-14.

Smith, G. G., Olkun, S. ve Middleton, J. A. (1999). Interactive versus observational learning of spatial visualization of geometric 
transformations. Paper presented at the annual meeting of the American Educational Research Association, Montreal, Kanada.

Stockdale, C. ve Possin, C. (1998). Spatial Relations and Learning ARK Foundation, Allenmore Medical Center. New Horizons for Learning.

Tekin, A. T. (2007). Dokuzuncu ve on birinci sınıf ögrencilerinin zihinde döndürme ve uzamsal görselleştirme yeteneklerinin karşllaştırmalı olarak incelenmesi. Yayımlanmamış yüksek lisans tezi, Ankara Üniversitesi.

Terao, A., Koedinger K., Sohn, M-H., Anderson, J. R. ve Carter, C. S. (2004). An fMRI study of the interplay of visual-spatial systems in mathematical reasoning. K. Forbus, D. Gentner, and T. Regier (Ed.), Proceedings of the 26th Annual Conference of the Cognitive Science Society içinde (1327-1332). Mahwah, NJ: Lawrence Erlbaum Associates.

Turgut, M. (2010). Teknoloji destekli lineer cebir öğretiminin ilköğretim matematik öğretmen adaylarının uzamsal yeteneklerine etkisi. Yayımlanmamış doktora tezi, Dokuz Eylül Üniversitesi Eğitim Bilimleri Enstitüsü.

Ubuz, B. ve Sarı, S. (2008). Sınıf öğretmeni adaylarının öğretmenlik mesleğini seçme nedenleri. Pamukkale Üniversitesi Ĕgitim Fakültesi Dergisi, 24(2), 113-119.

Usiskin, Z. (1982). Van Hiele levels and achievement in secondary school geometry. Final report of the Cognitive Development and achievement in secondary school geometry project, University of Chicago, Department of Education.

Uygan, C. (2011). Katı cisimlerin ögrretiminde google sketchup ve 
somut model destekli uygulamaların ilkögretim matematik öğretmeni adaylarının uzamsal yeteneklerine etkisi. Yayımlanmamış yüksek lisans tezi, Eskişehir Osmangazi Üniversitesi, Eğitim Bilimleri Enstitüsü.

Van Dooren, W., Verschaffel, L. ve Onghena, P. (2002). The impact of preservice teachers' content knowledge on their evaluation of students' strategies for solving arithmetic and algebra word problems. Journal for Research in Mathematics Education, 33(5), 319-351.

Van Hiele, P. M. (1986). Structure and insight. A theory of mathematics education. Orlando: Florida, Academic Press.

Wongyai, P. ve Kamol, N. (2004). A Framework in characterizing lower secondary school students' algebraic thinking. $21 \mathrm{Kas} 1 \mathrm{~m}$ 2012, http://www.icme-organisers.dk/tsg09/.

Yolcu, B. (2008). Altınc sınıf ögrencilerinin uzamsal becerilerinin somut modeller ve bilgisayar uygulamaları ile geliştirme çalışmaları. Yayımlanmamış yüksek lisans tezi, Eskişehir Osmangazi Üniversitesi. 
EK 1

\section{UZMAN GÖRÜŞ FORMU}

\begin{tabular}{|c|c|c|c|c|c|c|c|c|c|c|c|c|}
\hline \multirow{2}{*}{ Ë. } & \multicolumn{3}{|c|}{$\begin{array}{l}\text { Zorluk } \\
\text { Derecesi }\end{array}$} & \multicolumn{3}{|c|}{$\begin{array}{l}\text { Seviyeye } \\
\text { Uygunluk }\end{array}$} & \multicolumn{3}{|c|}{$\begin{array}{l}\text { Soruların } \\
\text { İfade } \\
\text { Edilişi }\end{array}$} & \multicolumn{3}{|c|}{$\begin{array}{lr}\text { Sorular } & \text { uzamsal } \\
\text { yetenek } & \text { bileşenine } \\
\text { göre } & \text { verilen } \\
\text { boyutlara } & \text { uygun } \\
\text { mu? } & \\
\end{array}$} \\
\hline & $\begin{array}{l}\vec{a} \\
\frac{0}{0} \\
1\end{array}$ & $\stackrel{\pi}{0}$ & $\stackrel{\grave{D}}{N}$ & 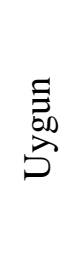 & 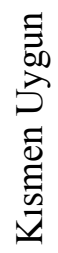 & 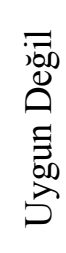 & $\frac{\Xi}{\exists}$ & 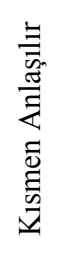 & 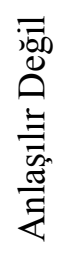 & $\begin{array}{l}\overrightarrow{0} \\
\vec{D}\end{array}$ & 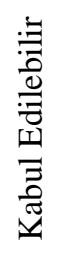 & 㝕 \\
\hline 1 & & & & & & & & & & & & \\
\hline 2 & & & & & & & & & & & & \\
\hline 3 & & & & & & & & & & & & \\
\hline 4 & & & & & & & & & & & & \\
\hline 5 & & & & & & & & & & & & \\
\hline 6 & & & & & & & & & & & & \\
\hline 7 & & & & & & & & & & & & \\
\hline 8 & & & & & & & & & & & & \\
\hline 9 & & & & & & & & & & & & \\
\hline 10 & & & & & & & & & & & & \\
\hline 11 & & & & & & & & & & & & \\
\hline 12 & & & & & & & & & & & & \\
\hline 13 & & & & & & & & & & & & \\
\hline 14 & & & & & & & & & & & & \\
\hline 15 & & & & & & & & & & & & \\
\hline 16 & & & & & & & & & & & & \\
\hline
\end{tabular}

